\title{
Co-Doped Rare-Earth (La, Pr) and Co-Al Substituted M-Type Strontium Hexaferrite: Structural, Magnetic, and Mossbauer Spectroscopy Study
}

\author{
Madhav L. Ghimire ${ }^{1,2 *}$, Dom L. Kunwar3 ${ }^{3}$ Jiba N. Dahal4, Dipesh Neupane1, Sunghyun Yoon ${ }^{5}$, \\ Sanjay R. Mishra ${ }^{1}$
}

${ }^{1}$ Department of Physics and Materials Science, The University of Memphis, Memphis, TN, USA

${ }^{2}$ Department of Physics, Virginia Commonwealth University, Richmond, VA, USA

${ }^{3}$ Department of Physics, Kent State University, Kent, OH, USA

${ }^{4}$ Department of Physics and Astronomy, Truman State University, Kirksville, MO, USA

${ }^{5}$ Department of Physics, Gunsan National University, Gunsan, South Korea

Email: ${ }^{\star}$ ghimirem@vcu.edu, madhav.ghim@gmail.com

How to cite this paper: Ghimire, M.L., Kunwar, D.L., Dahal, J.N., Neupane, D., Yoon, S. and Mishra, S.R. (2020) Co-Doped Rare-Earth (La, Pr) and Co-Al Substituted M-Type Strontium Hexaferrite: Structural, Magnetic, and Mossbauer Spectroscopy Study. Materials Sciences and Applications, 11, 474-493.

https://doi.org/10.4236/msa.2020.117033

Received: June 5, 2020

Accepted: July 17, 2020

Published: July 20, 2020

Copyright $\odot 2020$ by author(s) and Scientific Research Publishing Inc. This work is licensed under the Creative Commons Attribution International License (CC BY 4.0).

http://creativecommons.org/licenses/by/4.0/

\section{(c) (i) Open Access}

\begin{abstract}
The present study investigates the influence of $\mathrm{La}^{3+}$ and $\mathrm{Pr}^{3+}$ doping on the structural, magnetic properties, and hyperfine fields of $\mathrm{Sr}_{0.7} \mathrm{RE}_{0.3} \mathrm{Fe}_{12-2 \mathrm{x}} \mathrm{Co}_{\mathrm{x}-}$ $\mathrm{Al}_{\mathrm{x}} \mathrm{O}_{19},\left(\mathrm{RE}: \mathrm{La}^{3+}\right.$ and $\left.\mathrm{Pr}^{3+}, x=0.0-0.8\right)$ hexaferrite compounds prepared via auto-combustion technique. The XRD analysis shows a linear decrease in a and $c$ lattice and unit cell volume contraction with the content $x$. The room temperature magnetic study shows that for the $\mathrm{Pr}^{3+}$ doped $\mathrm{Sr}_{0.7} \mathrm{Pr}_{0.3} \mathrm{Fe}_{12-2 \mathrm{x}}$ $\mathrm{Co}_{\mathrm{x}} \mathrm{Al}_{\mathrm{x}} \mathrm{O}_{19}\left(\mathrm{Pr}^{3+}-\mathrm{SrM}\right)$, the magnetization value monotonically decreases while for $\mathrm{La}^{3+}$ doped $\mathrm{Sr}_{0.7} \mathrm{La}_{0.3} \mathrm{Fe}_{12-2 \mathrm{x}} \mathrm{Co}_{\mathrm{x}} \mathrm{Al}_{\mathrm{x}} \mathrm{O}_{19}\left(\mathrm{La}^{3+}-\mathrm{SrM}\right)$ magnetization value shows a noticeable increase in magnetization value with $x$. The coercivity of the $\mathrm{Pr}^{3+}-\mathrm{SrM}$ compound was observed to decrease while that of the $\mathrm{La}^{3+}-\mathrm{SrM}$ compound showed a marked $40 \%$ increase at $x=0.2(\sim 5829$ Oe $)$ in comparison to undoped $\mathrm{SrFe}_{12} \mathrm{O}_{19}(\sim 3918 \mathrm{Oe})$. A difference in Curie temperature was also observed, with $T c \sim 525^{\circ} \mathrm{C}$ at $x=0.4$ for $\operatorname{Pr}^{3+}$-SrM and $T c=505^{\circ} \mathrm{C}$ for $x=$ 0.4 for $\mathrm{La}^{3+}-\mathrm{SrM}$ compound. The observed differences in magnetic properties have been explained on the basis of the site occupancy of $\mathrm{Co}^{2+}$ and $\mathrm{Al}^{3+}$ in the presence of rare-earth ions. The presence of non-magnetic rare-earth ion, $\mathrm{La}^{3+}$, improved saturation magnetization, and coercivity and deemed suitable replacement for $\mathrm{Sr}^{2+}$. The hyperfine parameters namely quadrupole shift showed a decrease with the $\mathrm{La}^{3+}$ or $\mathrm{Pr}^{3+}$ doping independent of $\left(\mathrm{Co}^{2+}-\mathrm{Al}^{3+}\right)$ ions doping. Overall, the Mossbauer analysis suggests that the $\left(\mathrm{Co}^{2+}-\mathrm{Al}^{3+}\right)$ impurities prefer occupancy at $2 a$ site.
\end{abstract}




\section{Keywords}

Doped Hexaferrite, M-Type Hexaferrite, X-Ray Diffraction, Mossbauer Spectroscopy

\section{Introduction}

The M-type hexaferrite, Strontium hexaferrite, is an excellent candidate for technological applications because of its high uniaxial magneto-crystalline anisotropy, large magnetization, high permeability, low conductive losses, excellent chemical stability, corrosion resistance and excellent high-frequency response [1] [2] [3]. Strontium hexaferrite has been widely used as materials for industrial applications, such as in microwave devices, small motors, electromagnetic wave absorber, and ferroxdures [4] [5]. Besides this, the popularity of strontium hexaferrite is also due to its economic success, which is its low price per unit available magnetic energy and its wide availability. So far, efforts have been made to further improve electrical, dielectric and magnetic properties of strontium hexaferrite by means of doping, heat treatment, ion substitution, and processing conditions [6] [7] [8] [9] [10].

In M-type hexaferrite, the structure is comprised of 64 ions per hexagonal unit cell on 11 distinct basis sites. The $24 \mathrm{Fe}^{3+}$ iron atoms of a unit cell occupy five different interstitial sites: three octahedral sites $\left(2 a, 12 k\right.$, and $\left.4 f_{2}\right)$, one tetrahedral site $\left(4 f_{1}\right)$ and one trigonal bi-pyramidal site $(2 b)$. The coupling of these sites by superexchange interaction via $\mathrm{O}_{2}^{-}$gives rise to a ferrimagnetic structure. The sites $12 k, 2 a$, and $2 b$ are sites with spin up while sites $4 f_{2}$ and $4 f_{1}$ are sites with the downs-spin [10]. This provides an ample opportunity to tune the magnetic properties of M-type hexaferrite compound by carefully engineering site occupancy in favor of increasing net magnetization of the compound. In view of this, attempts are made with either partial substitution of $\mathrm{Sr}^{2+} \mathrm{or} \mathrm{Fe}^{3+}$ sites. For example, substitution with non-magnetic ions such as $\mathrm{Al}^{3+}$ [11] [12], $\mathrm{Zn}^{3+}$ [13], $\mathrm{Ga}^{3+}$ [14] and $\mathrm{Cd}^{3+}[15]$ [16] and magnetic ions such as $\mathrm{Co}^{2+}$ [17] and $\mathrm{Cr}^{3+}$ [18] at $\mathrm{Fe}$ sites, or with the partial substitution of $\mathrm{Sr}^{2+}$ site by $\mathrm{RE}^{3+}$ such as $\mathrm{La}^{3+}$ [19] [20], $\mathrm{Nd}^{3+}$ [21], $\mathrm{Sm}^{3+}$ [22] [23] and $\mathrm{Pr}^{3+}$ [24] ions, and substitution of $\mathrm{Sr}^{2+} / \mathrm{Fe}^{3+}$ together with Pr-Zn [25], La-Cu [26], and La-Zn [27]. The majority of these studies have attributed changes in the magnetic behavior of doped SrM either to the site-occupancy, which perturbs exchange interaction between $\mathrm{Fe}^{3+}-\mathrm{O}^{2-} \mathrm{Fe}^{3+}$, anisotropy changes occurring at $2 \mathrm{~b}$ sites due to perturbation in electric field gradient or extrinsic features such as particle size.

Doping of non-magnetic $\mathrm{Al}^{3+}$ in $\mathrm{SrFe}_{12-\mathrm{x}} \mathrm{Al}_{\mathrm{x}} \mathrm{O}_{19}$ has been reported to bring a considerable enhancement in the coercivity along with a reduction in saturation magnetization [11] [28] [29]. Thus with the $\mathrm{Al}^{3+}$ substitution, in spite of a large increase in the coercivity, the compound attains abysmal magnetization value. A strategy could be designed to keep both coercivity and magnetization value high. 
In the present work, an attempt is made to co-doped $\mathrm{Co}^{2+}-\mathrm{Al}^{3+}$ in the $\mathrm{SrFe}_{12} \mathrm{O}_{19}$ compound. Magnetic ion $\mathrm{Co}^{2+}\left(\sim 3.7 \mu_{\mathrm{B}}\right)$ is chosen to maintain high magnetization value, while $\mathrm{Al}^{3+}$ doping is expected to maintain high coercivity value in $\mathrm{SrFe}_{12} \mathrm{O}_{19}$. Furthermore, Lechevallier et al. reported that the only light rare-earth enters the structure, which a solubility that is related to the shape of the charge distribution of the $4 \mathrm{f}$ electrons to its surroundings in the crystal structure. Thus, only those rare-earth ions have easy accommodation at the $\mathrm{Sr}^{2+}$ site, whose surroundings favor an oblate electronic distribution. This makes $\mathrm{Pr}$ and $\mathrm{Nd}$ (with oblate $4 f$ charge distribution, negative Stevens constant) ideal candidate to occupy the $\mathrm{Sr}^{2+}$ site [25]. Furthermore, $\mathrm{Co}^{2+}$ ions were reported to modify the surroundings of the $\mathrm{Sr}^{2+}$ site, improving the introduction of rare-earth ios with oblate electronic distributions, in fact, the presence of $\mathrm{Co}^{2+}$ increases the solubility of $\mathrm{Pr}^{3+}$ [25]. Also, $\mathrm{RE}^{3+}-\mathrm{Co}^{2+}-\mathrm{Al}^{3+}$, co-substitution naturally maintains the charge neutrality condition in the compound. With the substitution of $\mathrm{RE}^{3+}$ for the $\mathrm{Sr}^{2+}$, the extra positive charge is compensated by the substitution of $\mathrm{Co}^{2+}$ at the $\mathrm{Fe}^{3+}$ site. In the absence of $\mathrm{Co}^{2+}$, one of the $\mathrm{Fe}^{3+}$ has to convert to $\mathrm{Fe}^{2+}$, which has a deleterious effect on the magnetization. With this strategy in mind, the present study investigates, the influence of the 1) rare-earth substitution, $\mathrm{Pr}^{3+}$, and $\mathrm{La}^{3+}$, at the $\mathrm{Sr}^{2+}$ site and 2) $\mathrm{Co}^{2+}-\mathrm{Al}^{3+}$ substitution at $\mathrm{Fe}^{3+}$ sites on the overall magnetic properties of the $\mathrm{Sr}_{0.7} \mathrm{RE}_{0.3} \mathrm{Fe}_{12-2 \mathrm{x}} \mathrm{Co}_{\mathrm{x}} \mathrm{Al}_{\mathrm{x}} \mathrm{O}_{19}$ compound.

\section{Experimental}

The series of $\mathrm{Sr}_{0.7} \mathrm{RE}_{0.3} \mathrm{Fe}_{12-2 \mathrm{x}} \mathrm{Co}_{\mathrm{x}} \mathrm{Al}_{\mathrm{x}} \mathrm{O}_{19}$ (RE: $\mathrm{La}^{3+}$ and $\mathrm{Pr}^{3+}, x=0,0.2,0.4,0.6$ and 0.8 ) compounds were prepared by auto-combustion method [11]. Nitrate salts of $\mathrm{Fe}\left(\mathrm{NO}_{3}\right)_{3} \cdot 9 \mathrm{H}_{2} \mathrm{O}$ (Sigma Aldrich, 99\%), $\mathrm{Sr}\left(\mathrm{NO}_{3}\right)_{2}$ (Sigma Aldrich, 99\%), $\mathrm{Al}\left(\mathrm{NO}_{3}\right)_{3} \cdot 9 \mathrm{H}_{2} \mathrm{O}$ (Sigma Aldrich, 99\%), $\mathrm{RE}\left(\mathrm{NO}_{3}\right)_{3} \cdot 9 \mathrm{H}_{2} \mathrm{O}$ (Sigma Aldrich, 99\%) and $\mathrm{C}_{6} \mathrm{H}_{8} \mathrm{O}_{7}$ (Sigma Aldrich, 99\%) were selected for the synthesis $\mathrm{Sr}_{0.7} \mathrm{RE}_{0.3} \mathrm{Fe}_{12-2 \mathrm{x}}$ $\mathrm{Co}_{\mathrm{x}} \mathrm{Al}_{\mathrm{x}} \mathrm{O}_{19}$ compounds. The stoichiometric amount of nitrates salts and citric acid were mixed in $25 \mathrm{ml}$ of deionized water under constant stirring on a hot plate at $80^{\circ} \mathrm{C}$ for about 30 minutes. Aqueous ammonia was added dropwise in the homogeneous mixture until the $\mathrm{pH}$ value of the solution reached 6.5. The intermediate precipitate was heated at $100^{\circ} \mathrm{C}$ on a hot plate under stirring until the viscous brown gel is formed. The temperature is suddenly increased to $300^{\circ} \mathrm{C}$ to turn it into magnetic powder. Powders were calcined in air at $1000^{\circ} \mathrm{C}$ for twelve hours. The precursor used in the preparation of $1 \mathrm{~g}$ of sample is listed in Table 1.

The crystal structure and phase purity of the obtained samples were identified by analyzing $X$-ray diffraction (XRD) pattern collected via Bruker D8 Advance $\mathrm{X}$-ray diffractometer using $\mathrm{Cu} \mathrm{K}_{\alpha}$ radiation source $(\lambda \sim 0.154056 \mathrm{~nm})$. Vibrating sample magnetometer (VSM) was used to collect hysteresis loops of the samples at room temperature in the maximum field of $1.2 \mathrm{~T}$. Curie temperature, $T \mathcal{c}$, were measured using Thermogravimetric analyzer, TGA, (DuPont 910) equipped with a permanent magnet. Room temperature ${ }^{57} \mathrm{Fe}$ Mossbauer spectroscopy was 
Table 1. Stoichiometry weight of of $\mathrm{SrFe}_{12} \mathrm{O}_{19}, \mathrm{Sr}_{0.7} \mathrm{La}_{0.3} \mathrm{Fe}_{12-2 \mathrm{x}} \mathrm{Co}_{\mathrm{x}} \mathrm{Al}_{\mathrm{x}} \mathrm{O}_{19}$ and $\mathrm{Sr}_{0.7} \mathrm{Pr}_{0.3} \mathrm{Fe}_{12-2 \mathrm{x}} \mathrm{Co}_{\mathrm{x}} \mathrm{Al}_{\mathrm{x}} \mathrm{O}_{19}$.

\begin{tabular}{|c|c|c|c|c|c|c|}
\hline \multicolumn{7}{|c|}{ Mass (g) } \\
\hline & $\mathrm{Sr}\left(\mathrm{NO}_{3}\right)_{2}$ & $\mathrm{La}\left(\mathrm{NO}_{3}\right)_{2} \cdot 6 \mathrm{H}_{2} \mathrm{O}$ & $\mathrm{Fe}\left(\mathrm{NO}_{3}\right)_{2} \cdot 9 \mathrm{H}_{2} \mathrm{O}$ & $\mathrm{Co}\left(\mathrm{NO}_{3}\right)_{2} \cdot 6 \mathrm{H}_{2} \mathrm{O}$ & $\mathrm{Al}\left(\mathrm{NO}_{3}\right)_{2} \cdot 9 \mathrm{H}_{2} \mathrm{O}$ & Citric acid \\
\hline $\mathrm{SrFe}_{12} \mathrm{O}_{19}$ & 0.199 & 0.000 & 4.567 & 0.000 & 0.000 & 2.573 \\
\hline $\mathrm{Sr}_{0.7} \mathrm{Lar}_{0.3} \mathrm{Fe}_{12-2 \mathrm{x}} \mathrm{Co}_{\mathrm{x}} \mathrm{Al}_{\mathrm{x}} \mathrm{O}_{19}$ & & & & & & \\
\hline$x=0.0$ & 0.176 & 0.361 & 4.038 & 0.000 & 0.000 & 2.275 \\
\hline$x=0.2$ & 0.175 & 0.359 & 3.951 & 0.048 & 0.062 & 2.264 \\
\hline$x=0.4$ & 0.175 & 0.357 & 3.865 & 0.096 & 0.124 & 2.253 \\
\hline$x=0.6$ & 0.174 & 0.355 & 3.780 & 0.143 & 0.185 & 2.241 \\
\hline$x=0.8$ & 0.173 & 0.354 & 3.695 & 0.190 & 0.245 & 2.230 \\
\hline $\mathrm{Sr}_{0.7} \mathrm{Pr}_{0.3} \mathrm{Fe}_{12-2 \mathrm{x}} \mathrm{Co}_{\mathrm{x}} \mathrm{Al}_{\mathrm{x}} \mathrm{O}_{19}$ & & $\operatorname{Pr}\left(\mathrm{NO}_{3}\right)_{2} \cdot 6 \mathrm{H}_{2} \mathrm{O}$ & & & & \\
\hline$x=0.0$ & 0.137 & 0.125 & 4.499 & 0.000 & 0.000 & 2.535 \\
\hline$x=0.2$ & 0.137 & 0.124 & 4.400 & 0.054 & 0.069 & 2.521 \\
\hline$x=0.4$ & 0.136 & 0.123 & 4.301 & 0.107 & 0.138 & 2.507 \\
\hline$x=0.6$ & 0.135 & 0.123 & 4.204 & 0.159 & 0.205 & 2.493 \\
\hline$x=0.8$ & 0.134 & 0.122 & 4.107 & 0.211 & 0.272 & 2.480 \\
\hline
\end{tabular}

employed to derive hyperfine parameters. The Mossbauer spectrometer (SEE Co. Minneapolis, MN USA) was calibrated against $\alpha$-Fe foil. The Mossbauer spectra were analyzed using WMOSS software (SEE Co. Minneapolis, MN USA).

\section{Results and Discussions}

The room temperature XRD pattern of $\mathrm{Sr}_{0.7} \mathrm{RE}_{0.3} \mathrm{Fe}_{12-2 \mathrm{x}} \mathrm{Co}_{\mathrm{x}} \mathrm{Al}_{\mathrm{x}} \mathrm{O}_{19}$ (RE: $\mathrm{La}^{3+}$ and $\operatorname{Pr}^{3+}, x=0.0,0.2,0.4,0.6$, and 0.8$)$ is shown in Figure 1. XRD patterns of the substituted compounds indicated the presence of a magnetoplumbite structure (ICCD 080-1198) corresponding to the hexagonal P63/mmc symmetry phase group without any secondary phase. The lattice parameters of the compound were calculated from their inter-planar spacing $d_{h k l}$ corresponding to the major peaks (107), (114), and (008) using equation [30]:

$$
d_{(h k l)}=\left(\frac{4\left(h^{2}+h k+k^{2}\right)}{3 a^{2}}+\frac{l^{2}}{c^{2}}\right)^{-\frac{1}{2}}
$$

where $h, k$, and $l$ are Miller indices. The calculated lattice parameters $a$ and $c$ of the hexaferrites are shown in Table 2. The plot for $a$ and $c$ as a function of doping content is shown in Figure 2. A linear decrease in the lattice parameters a and $c$ with the doping content was observed. The linear decrease in the lattice parameter may occur due to the substitution of $\mathrm{Al}^{3+}$ (ionic radii, $r \sim 0.51 \AA$ ) and 


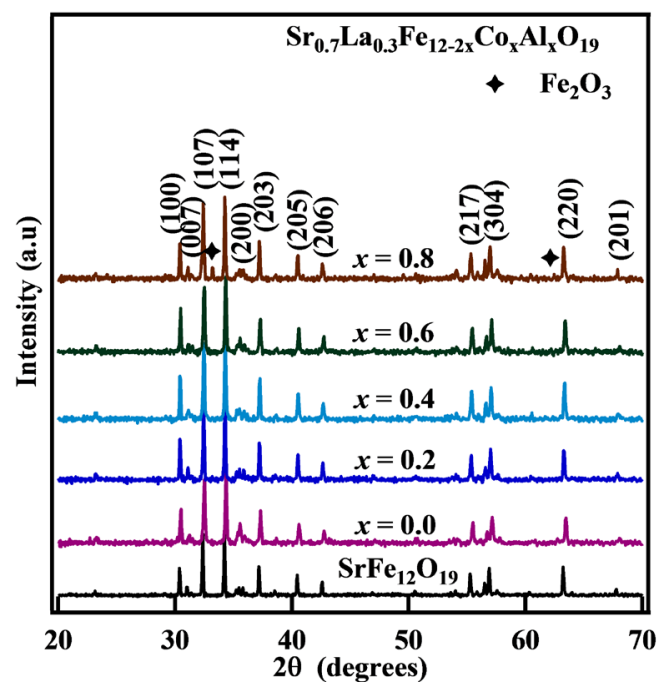

(a)

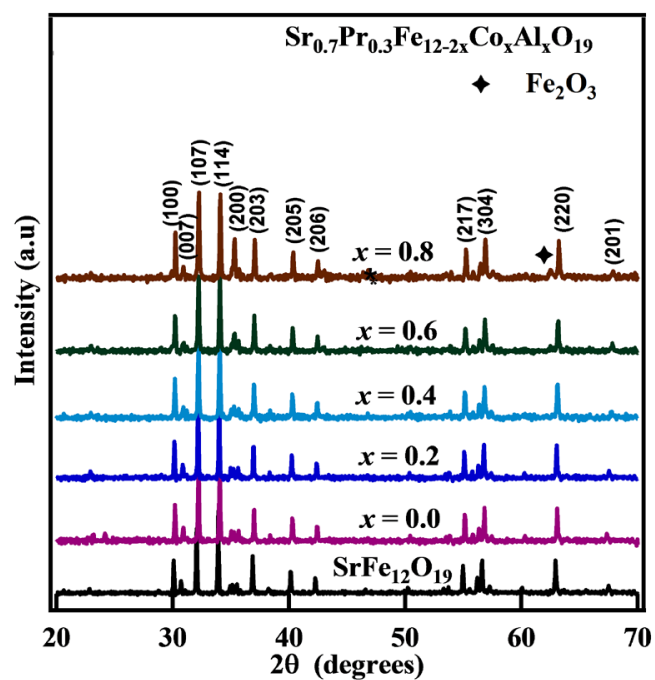

(b)

Figure 1. X-ray diffraction pattern of (a) $\mathrm{Sr}_{0.7} \mathrm{La}_{0.3} \mathrm{Fe}_{12-2 \mathrm{x}} \mathrm{Co}_{\mathrm{x}} \mathrm{Al}_{\mathrm{x}} \mathrm{O}_{19}$ and (b) $\mathrm{Sr}_{0.7} \mathrm{Pr}_{0.3} \mathrm{Fe}_{12-2 \mathrm{x}} \mathrm{Co}_{\mathrm{x}} \mathrm{Al}_{\mathrm{x}} \mathrm{O}_{19}$ obtained using $\mathrm{Cu} \mathrm{Ka}$ radiation.
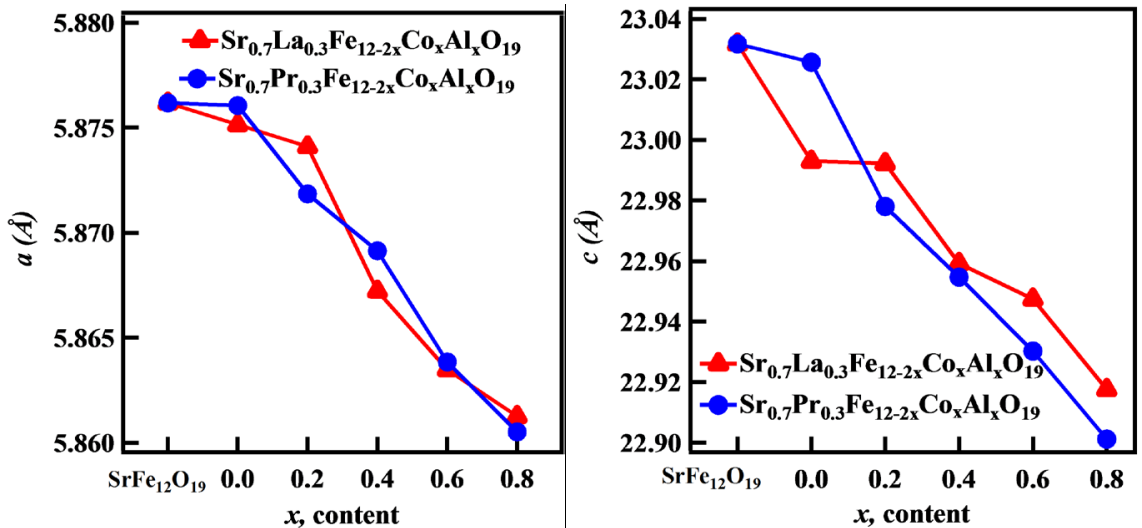

Figure 2. Lattice parameters of $\mathrm{Sr}_{0.7} \mathrm{La}_{0.3} \mathrm{Fe}_{12-2 \mathrm{x}} \mathrm{Co}_{\mathrm{x}} \mathrm{Al}_{\mathrm{x}} \mathrm{O}_{19}$ and $\mathrm{Sr}_{0.7} \mathrm{Pr}_{0.3} \mathrm{Fe}_{12-2 \mathrm{x}} \mathrm{Co}_{\mathrm{x}} \mathrm{Al}_{\mathrm{x}} \mathrm{O}_{19}$ as a function of content, $\mathrm{x}$, derived from $\mathrm{X}$-ray diffraction pattern. 
Table 2. Lattice parameters of $\mathrm{SrFe}_{12} \mathrm{O}_{19}, \mathrm{Sr}_{0.7} \mathrm{La}_{0.3} \mathrm{Fe}_{12-2 \mathrm{x}} \mathrm{Co}_{\mathrm{x}} \mathrm{Al}_{\mathrm{x}} \mathrm{O}_{19}$ and $\mathrm{Sr}_{0.7} \mathrm{Pr}_{0.3} \mathrm{Fe}_{12-2 \mathrm{x}} \mathrm{Co}_{\mathrm{x}} \mathrm{Al}_{\mathrm{x}} \mathrm{O}_{19}$ as obtained from $\mathrm{XRD}$ pattern using Equation (1) and crystalline size using Equation (2).

\begin{tabular}{|c|c|c|c|c|c|}
\hline & $\mathrm{a}(\AA)$ & $c(\AA)$ & $\mathrm{V}\left(\AA^{3}\right)$ & $c / a$ & Crystallite size (nm) \\
\hline $\mathrm{SrFe}_{12} \mathrm{O}_{19}$ & 5.876 & 23.031 & 686.707 & 3.919 & 80.77 \\
\hline \multicolumn{6}{|c|}{$\mathrm{Sr}_{0.7} \mathrm{La}_{0.3} \mathrm{Fe}_{12-2 \mathrm{x}} \mathrm{Co}_{\mathrm{x}} \mathrm{Al}_{\mathrm{x}} \mathrm{O}_{19}$} \\
\hline$x=0.0$ & 5.856 & 22.936 & 688.498 & 3.919 & 58.345 \\
\hline$x=0.2$ & 5.869 & 22.995 & 686.086 & 3.913 & 65.900 \\
\hline$x=0.4$ & 5.867 & 22.943 & 684.758 & 3.911 & 61.670 \\
\hline$x=0.6$ & 5.860 & 22.964 & 682.798 & 3.910 & 59.465 \\
\hline$x=0.8$ & 5.869 & 23.012 & 681.155 & 3.908 & 56.070 \\
\hline \multicolumn{6}{|c|}{$\mathrm{Sr}_{0.7} \mathrm{Pr}_{0.3} \mathrm{Fe}_{12-2 \mathrm{x}} \mathrm{Co}_{\mathrm{x}} \mathrm{Al}_{\mathrm{x}} \mathrm{O}_{19}$} \\
\hline$x=0.0$ & 5.873 & 23.034 & 687.308 & 3.914 & 60.825 \\
\hline$x=0.2$ & 5.923 & 23.076 & 687.038 & 3.914 & 76.640 \\
\hline$x=0.4$ & 5.915 & 23.047 & 684.448 & 3.913 & 65.985 \\
\hline$x=0.6$ & 5.911 & 23.027 & 683.225 & 3.914 & 67.210 \\
\hline$x=0.8$ & 5.904 & 23.035 & 681.995 & 3.911 & 65.000 \\
\hline
\end{tabular}

$\mathrm{Co}^{2+}(r \sim 0.72 \AA)$ for $\mathrm{Fe}^{3+}(r \sim 0.64 \AA)$ and smaller $\mathrm{La}^{3+}(r \sim 1.172 \AA)$ and $\operatorname{Pr}^{3+}(r \sim$ $1.13 \AA)$ for the $\mathrm{Sr}^{2+}(r \sim 1.32 \AA)$ ions [31]. According to Wagner [32], an examination of $c /$ a parameter ratio may be used to quantify the structure type, as the M-type (magnetoplumbite) structure can be assumed if the ratio is observed to be in the range 3.917 and 3.963. As per Table 2, the $c / a$ ratios of as-prepared samples are in the range of 3.908 to 3.919 , assuring that the as-prepared samples have maintained the M-type structure.

The crystallite size of as-synthesized particles was calculated using Scherrer's equation [33]:

$$
D(h k l)=k \lambda /(\beta \cos \vartheta)
$$

where $k$ denotes the Scherrer constant $(k=0.9), \lambda$ is the wavelength of $\mathrm{x}$-ray source $(\lambda=0.154056 \mathrm{~nm}), \beta$ is the full-width-half-maximum of a diffraction peak and $\theta$ is the diffraction angle. As listed in Table 2, the crystallite size of as-synthesized samples is in the range of 54 to $77 \mathrm{~nm}$. In the comparison of the pure $\mathrm{SrFe}_{12} \mathrm{O}_{19}$ sample with a crystallite size of $80.7 \mathrm{~nm}$, the doped compounds show reduced crystallite size. Grain refinement is usually observed in rare-earth and doped oxide compounds [34]. This grain refinement is reported to result from the 1) increased microstrain and defect density with substitution content and 2) diffusion of substituent element to the grain boundaries, the migration that restrains the grain growth by lowering down the grain growth mobility. If the retarding force generated is more than the driving force for the grain growth due to dopants, the movement of the grain boundary is impeded [35]. 
The room temperature hysteresis loops, $M$ vs. $H$, of $\mathrm{Sr}_{0.7} \mathrm{RE}_{0.3} \mathrm{Fe}_{12-2 \mathrm{x}} \mathrm{Co}_{\mathrm{x}} \mathrm{Al}_{\mathrm{x}} \mathrm{O}_{19}$ are shown in Figure 3. The magnetic parameters viz. saturation magnetization, $M s$, remanence, $M r$, and coercivity, $H c$ were extracted from the hysteresis loops and are listed in Table 3. The $M$ vs. $H$ curves show hard ferrites behaviors with high coercivity. The magnetic properties have been changed significantly upon $\mathrm{RE}^{3+}$ and $\mathrm{Co}^{2+}-\mathrm{Al}^{3+}$ substitution in $\mathrm{Sr}_{0.7} \mathrm{RE}_{0.3} \mathrm{Fe}_{12-2 \mathrm{x}} \mathrm{Co}-\mathrm{Al}_{\mathrm{x}} \mathrm{O}_{19}$ as compared to undoped ferrite $\mathrm{SrFe}_{12} \mathrm{O}_{19}$. The $M s$ value of $\mathrm{Pr}^{3+}-\mathrm{SrM}$ is observed to have a maximum value of $86 \mathrm{emu} / \mathrm{g}$ for $x=0.2$ but decreases with $\mathrm{Co}^{2+}-\mathrm{Al}^{3+}$ content and achieves a minimum value of $65 \mathrm{emu} / \mathrm{g}$ for $x=0.8$. However, in the case of $\mathrm{La}^{3+}-\mathrm{SrM}$, the $M s$ increases with $x$ and attains a maximum value of $87 \mathrm{emu} / \mathrm{g}$ at $x$ $=0.8$. As compared to pure $\mathrm{SrFe}_{12} \mathrm{O}_{19}, \mathrm{La}^{3+}-\mathrm{SrM}$ displays a noticeable $20 \%$ enhancement while $\mathrm{Pr}^{3+}-\mathrm{SrM}$ shows a $10 \%$ reduction in the $M s$ value. The variation of $M r$ and $M s$ as a function of $x$ content is shown in Figure 4. The value of $M r$ follows a trend similar to that of $M s$. As explained in the Mossbauer section, for series of compounds shows the marked preference of $\mathrm{Co}^{2+}-\mathrm{Al}^{3+}$ for the 2 a site, a site with the spin-up moment. Despite the substitution of $\mathrm{Co}^{2+}-\mathrm{Al}^{3+}$ at the $2 a$ site with the up-spin moment, the magnetization of $\mathrm{La}^{3+}-\mathrm{SrM}$ displayed a marked increase in the magnetization value with the substitution. A possible explanation for this observation is that the substitution of non-magnetic $\mathrm{La}^{3+}$ at the $\mathrm{Sr}^{2+} 1$ ) could enhance hyperfine fields at $12 \mathrm{k}$ site due to strengthening in the $\mathrm{Fe}^{3+}-\mathrm{O}^{2-} \mathrm{Fe}^{3+}$ superexchange interaction giving higher net magnetization. This increase in the hyperfine field of $12 k$ site is evident from the Mossabuer analysis, and 2) may increase the spin canting at the near-neighbor $4 f 2$ site $\left(\mathrm{Sr}^{2+}-4 f 2 \sim\right.$ $0.366 \mathrm{~nm}$ ), which results in a positive contribution to the overall magnetic moment. However, the possibility of $\mathrm{Co}^{2+}$ occupying a $4 f 2$ site cannot be ignored, which increases the net positive moment per unit cell of the compound [36] [37]

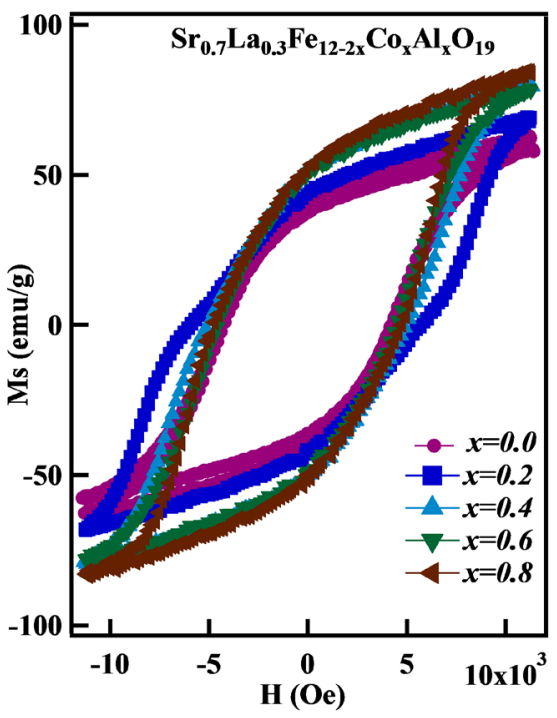

(a)

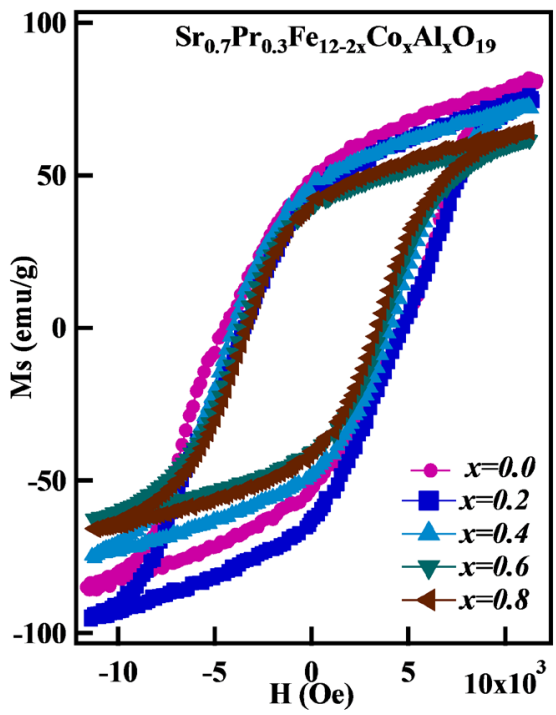

(b)

Figure 3. Room temperature VSM $M$ vs. $\mathrm{H}$ loops of (a) $\mathrm{Sr}_{0.7} \mathrm{La}_{0.3} \mathrm{Fe}_{12-2 \mathrm{x}} \mathrm{Co}_{\mathrm{x}} \mathrm{Al}_{\mathrm{x}} \mathrm{O}_{19}$ and (b) $\mathrm{Sr}_{0.7} \mathrm{Pr}_{0.3} \mathrm{Fe}_{12-2 \mathrm{x}} \mathrm{Co}_{\mathrm{x}} \mathrm{Al}_{\mathrm{x}} \mathrm{O}_{19}$. 
Table 3. Magnetic parameters of $\mathrm{SrFe}_{12} \mathrm{O}_{19}, \mathrm{Sr}_{0.7} \mathrm{La}_{0.3} \mathrm{Fe}_{12-2 \mathrm{x}} \mathrm{Co}_{\mathrm{x}} \mathrm{Al}_{\mathrm{x}} \mathrm{O}_{19}$ and $\mathrm{Sr}_{0.7} \mathrm{Pr}_{0.3} \mathrm{Fe}_{12-2 \mathrm{x}} \mathrm{Co}_{\mathrm{x}} \mathrm{Al}_{\mathrm{x}} \mathrm{O}_{19}$ measured using VSM. Curie temperature, Tc, of samples was measured using TGA.

\begin{tabular}{|c|c|c|c|c|c|}
\hline & $\mathrm{Ms}(\mathrm{emu} / \mathrm{g})$ & $\mathrm{Mr}(\mathrm{emu} / \mathrm{g})$ & $\mathrm{Mr} / \mathrm{Ms}$ & $\mathrm{Hc}(\mathrm{Oe})$ & $\operatorname{Tc}\left({ }^{\circ} \mathrm{C}\right)$ \\
\hline $\mathrm{SrFe}_{12} \mathrm{O}_{19}$ & 72.35 & 44.71 & 0.61 & 3918 & 458.60 \\
\hline \multicolumn{6}{|c|}{$\mathrm{Sr}_{0.7} \mathrm{La}_{0.3} \mathrm{Fe}_{12-2 \mathrm{x}} \mathrm{Co}_{\mathbf{x}} \mathrm{Al}_{\mathbf{x}} \mathrm{O}_{19}$} \\
\hline$x=0.0$ & 58.44 & 40.14 & 0.69 & 4318 & 477.80 \\
\hline$x=0.2$ & 69.22 & 43.62 & 0.63 & 5829 & 427.13 \\
\hline$x=0.4$ & 79.67 & 51.50 & 0.65 & 5031 & 506.00 \\
\hline$x=0.6$ & 78.00 & 49.97 & 0.63 & 4498 & 492.38 \\
\hline$x=0.8$ & 86.64 & 51.91 & 0.60 & 4761 & 455.75 \\
\hline \multicolumn{6}{|c|}{$\mathrm{Sr}_{0.7} \mathrm{Pr}_{0.3} \mathrm{Fe}_{12-2 \mathrm{x}} \mathrm{Co}_{\mathbf{x}} \mathrm{Al}_{\mathrm{x}} \mathrm{O}_{19}$} \\
\hline$x=0.0$ & 83.40 & 50.88 & 0.61 & 4651 & 456.63 \\
\hline$x=0.2$ & 86.09 & 52.81 & 0.61 & 4090 & 428.75 \\
\hline$x=0.4$ & 74.10 & 48.05 & 0.65 & 4130 & 523.56 \\
\hline$x=0.6$ & 62.20 & 39.97 & 0.64 & 3659 & 505.30 \\
\hline$x=0.8$ & 65.40 & 41.52 & 0.63 & 3379 & 489.19 \\
\hline
\end{tabular}
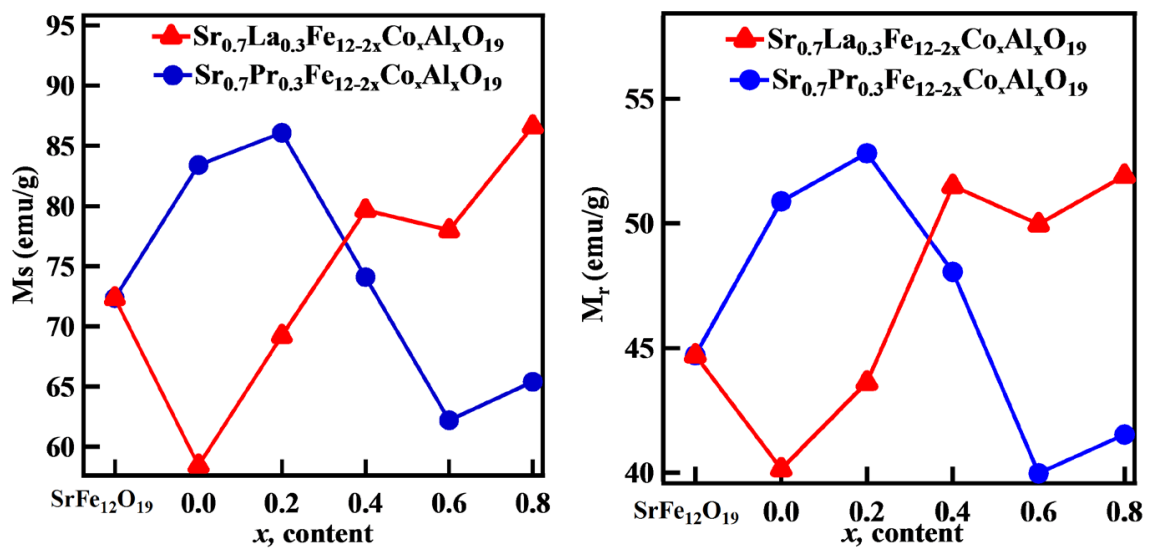

Figure 4. Room temperature $\mathrm{Ms}$ and $\mathrm{Mr}$ of $\mathrm{Sr}_{0.7} \mathrm{La}_{0.3} \mathrm{Fe}_{12-2 \mathrm{x}} \mathrm{Co}_{\mathrm{x}} \mathrm{Al}_{\mathrm{x}} \mathrm{O}_{19}$ and $\mathrm{Sr}_{0.7} \mathrm{Pr}_{0.3} \mathrm{Fe}_{12-2 \mathrm{x}} \mathrm{Co}_{\mathrm{x}} \mathrm{Al}_{\mathrm{x}} \mathrm{O}_{19}$ measured at $1.2 \mathrm{~T}$ field as a function of content, $x$.

[39]. On the other hand, the substitution of magnetic $\mathrm{Pr}^{3+}$ at the $\mathrm{Sr}^{2+}$ site may not allow spin-canting at the $4 f 2$ site, and with the replacement of $\mathrm{Fe}^{3+}$ at the $2 a$ site, the overall magnetic moment decreases in the $\mathrm{Pr}^{3+}-\mathrm{SrM}$ compounds.

The variation of coercivity, $H c$, of $\mathrm{La}^{3+}-\mathrm{SrM}$ and $\mathrm{Pr}^{3+}-\mathrm{SrM}$ compounds as a function of $x$ content is shown in Figure 5. Consistently $\mathrm{La}^{3+}-\mathrm{SrM}$ samples display higher $H c$ values than $\mathrm{Pr}^{3+}$-SrM compounds for all $x$ values. The $H c$ value of $\mathrm{La}^{3+}$-SrM displays a marked $\sim 50 \%$ increase at $X=0.2$ when compared to that of pure $\mathrm{SrFe}_{12} \mathrm{O}$ ( $\left.H c \sim 3918 \mathrm{Oe}\right)$. On the other hand, $H c$ value decreases linearly with increasing the $x$ content for the $\mathrm{Pr}^{3+}-\mathrm{SrM}$ compound. Being an extrinsic 


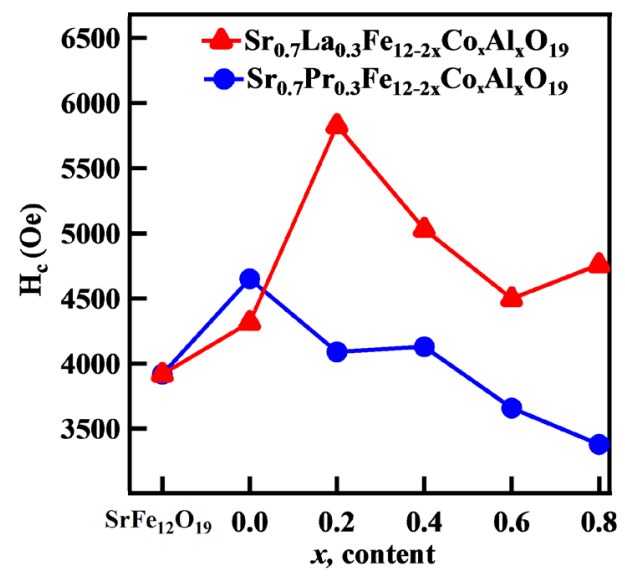

Figure 5. Coercivity, $\mathrm{Hc}$, of $\mathrm{Sr}_{0.7} \mathrm{La}_{0.3} \mathrm{Fe}_{12-2 \mathrm{x}} \mathrm{Co}_{\mathrm{x}} \mathrm{Al}_{\mathrm{x}} \mathrm{O}_{19}$ and $\mathrm{Sr}_{0.7} \mathrm{Pr}_{0.3} \mathrm{Fe}_{12-2 \mathrm{x}} \mathrm{Co}_{\mathrm{x}} \mathrm{Al}_{\mathrm{x}} \mathrm{O}_{19}$ as a function of content, $x$.

property, the coercivity depends on factors such as crystal structure, morphological features, elemental composition, and defects. In general, $H c$ can be expressed as,

$$
H_{c}=\left(\alpha\left(2 K 1 /\left(\mu_{o} M_{s}\right)\right)-N\left(M_{r}+M_{s}\right) / \mu_{o}\right.
$$

where $\alpha$ is the microstructure factor which has a reciprocal dependence on the grain size, $\mathrm{N}$ is the demagnetization factor, $2 K 1 /\left(\mu_{o} M_{s}\right)$ is the $H a$ is the magnetocrystalline anisotropy field [39]. In the M-type hexaferrite, magnetocrystalline anisotropy mainly originates from $\mathrm{Fe}^{3+}$ ions at the $2 b$ and $4 f 1$ site [40] [41]]. It has been reported that $\mathrm{Al}^{3+}$ ions have a preference for $4 f 2,2 a$, and $12 k$ sites, [42] [43], and $\mathrm{Co}^{2+}$ ions mainly prefer $4 f 2$ (mainly) and 2a sites [37] [38] [44]. In accordance with the Mossbauer analysis, discussed later, it is observed that in both series of samples studied herein, the $\mathrm{Co}^{3+}-\mathrm{Al}^{3+}$ ions have a preference for the $2 \mathrm{a}$ site. Thus the intrinsic coercivity as per Equation (3), should increase for both series of samples due to the increase in the magnetocrystalline anisotropy, as the site $2 b$ remains unaffected with the said substitution. However, from Figure 5 , it is observed that the $\mathrm{La}^{3+}$-SrM sample shows a maximum (5829 Oe) in coercivity value at $x=0.2$, followed by a decrease with increasing $x$ content in the sample. On the other hand, the $H c$ value of the $\operatorname{Pr}^{3+}-$ SrM sample shows a monotonous decrease with the $x$ content in the sample. Also, the $\mathrm{La}^{3+}$-SrM sample displays consistently higher coercive field value as compared to $\mathrm{Pr}^{3+}$-SrM. In a comparative study on $\operatorname{Sr}(\mathrm{La} / \mathrm{Pr}) \mathrm{Fe}_{12} \mathrm{O}_{19}$ samples it was reported that the $\operatorname{Pr}^{3+}$ doped $\operatorname{Sr}(\mathrm{Pr}) \mathrm{Fe}_{12} \mathrm{O}_{19}$ displayed higher coercivity than $\mathrm{La}^{3+}$ doped $\mathrm{Sr}(\mathrm{Pr}) \mathrm{Fe}_{12} \mathrm{O}_{19}$ sample because of the higher magnetocrystalline anisotropy of the former. However, the contrary results in the present study can be explained by taking microstructure factor, $\alpha$, in account in Equation (3) above. The $\mathrm{La}^{3+}-\mathrm{SrM}$ samples have relatively smaller crystallite size as compared to $\mathrm{Pr}^{3+}-\mathrm{SrM}$; as a result, the microstructure factor, $\alpha$, will have a higher value than that of $\operatorname{Pr}^{3+}-$ SrM sample. This will make the first term in the Equation (3) above greater than for $\mathrm{La}^{3+}-\mathrm{SrM}$ as compared to that for $\mathrm{Pr}^{3+}-\mathrm{SrM}$. The observed decrease in coercivity with the substitution 
could be attributed to the fact that the second term in the Equation (3) decreases much rapidly as compared to the $\alpha \mathrm{Ha}$ term.

The Curie temperature, $T c$, of $\mathrm{Sr}_{0.7} \mathrm{RE}_{0.3} \mathrm{Fe}_{12-2 \mathrm{x}} \mathrm{Co}_{\mathrm{x}} \mathrm{Al}_{\mathrm{x}} \mathrm{O}_{19}$ are shown in Figure 6. The maximum $T c$ value for $\mathrm{La}^{3+}-\mathrm{SrM}$ and $\mathrm{Pr}^{3+}-\mathrm{SrM}$ was observed to be 505 and $525 \mathrm{~K}$, respectively at $x=0.40$. After attaining maximum value, the $T c$ decreases gradually for $x>0.40$. The overall decrease in $T c$ after attaining maximum can be explained on the basis of three combined effects [45] [46], 1) substitution of $\mathrm{Co}^{2+}-\mathrm{Al}^{3+}$ ions for $\mathrm{Fe}^{3+}$ ions reduce the $\mathrm{Fe}^{3+}$ ions and hence leads to a reduction of $\mathrm{Fe}^{3+}-\mathrm{O}^{2-}-\mathrm{Fe}^{3+}$ number of superexchange interaction and strength and 2) lattice contraction with the substitution alters the bond length and angle of $\mathrm{Fe}^{3+}-\mathrm{O}^{2-}-\mathrm{Fe}^{3+}$ from its optimum interaction strength value. However, in the beginning, Tc drops down for $x=0.20$, where presumably $\mathrm{Fe}^{3+}$ might be substituted more with non-magnetic $\mathrm{Al}^{3+}$ and above combined effect become prevalent. However, the increasing magnetic $\mathrm{Co}^{2+}$ ion content helps regain the strength of the superexchange interaction and hence increases the $T c$ value for $x$ $=0.40[47]$.

In order to investigate the site occupancies of transition metal ions and resulting hyperfine parameters in the samples, Mossbauer spectra were collected at room temperature. Figure 7 shows the fitted Mossbauer spectra as a function of content $x$ in the as-synthesized samples. All spectra consist of five Lorentzian sextets originating from $12 k, 4 f 1,4 f 2,2 a$, and $2 b$ crystallographic sites of $\mathrm{Fe}^{3+}$ ions. The spectra were fitted with the constrain that all the linewidths of the absorption lines were the same. The extracted Mossbauer parameters are listed in Table 4(a) and Table 4(b). The observed sequences of the magnetic hyperfine magnetic fields, HF $(4 f 2>2 a>4 f 1>12 k>2 b)$ and isomer shift, $\delta$ (the isomer shifts follow the sequence of $4 f 2>12 k>2 a>2 b>4 f 1$ ) for both samples are in agreement with the reported results [47].

It is well known that the magnitude of the hyperfine magnetic field at the $\mathrm{Fe}^{3+}$ site depends on the distribution of neighboring magnetic cations. The hyperfine field, $H F$, the parameter of the most intense $12 k$ line effectively shows no variation

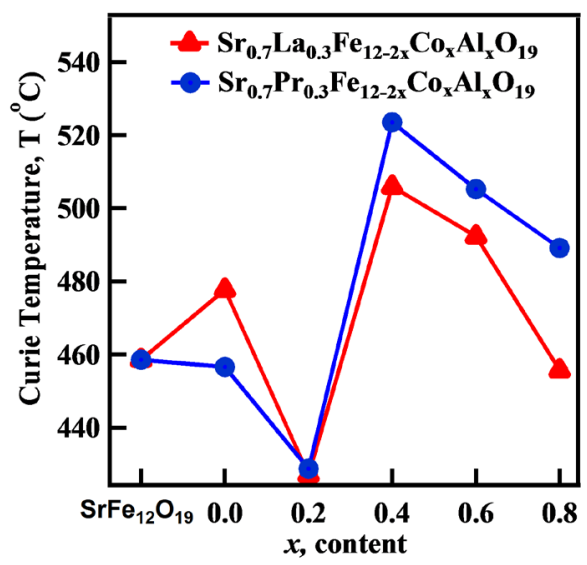

Figure 6. Curie temperature, Tc, of $\mathrm{Sr}_{0.7} \mathrm{La}_{0.3} \mathrm{Fe}_{12-2 \mathrm{x}} \mathrm{Co}_{\mathrm{x}} \mathrm{Al}_{\mathrm{x}} \mathrm{O}_{19}$ and $\mathrm{Sr}_{0.7} \mathrm{Pr}_{0.3} \mathrm{Fe}_{12-2 \mathrm{x}} \mathrm{Co}_{\mathrm{x}} \mathrm{Al}_{\mathrm{x}} \mathrm{O}_{19}$ as a function of content, $\mathrm{x}$. 


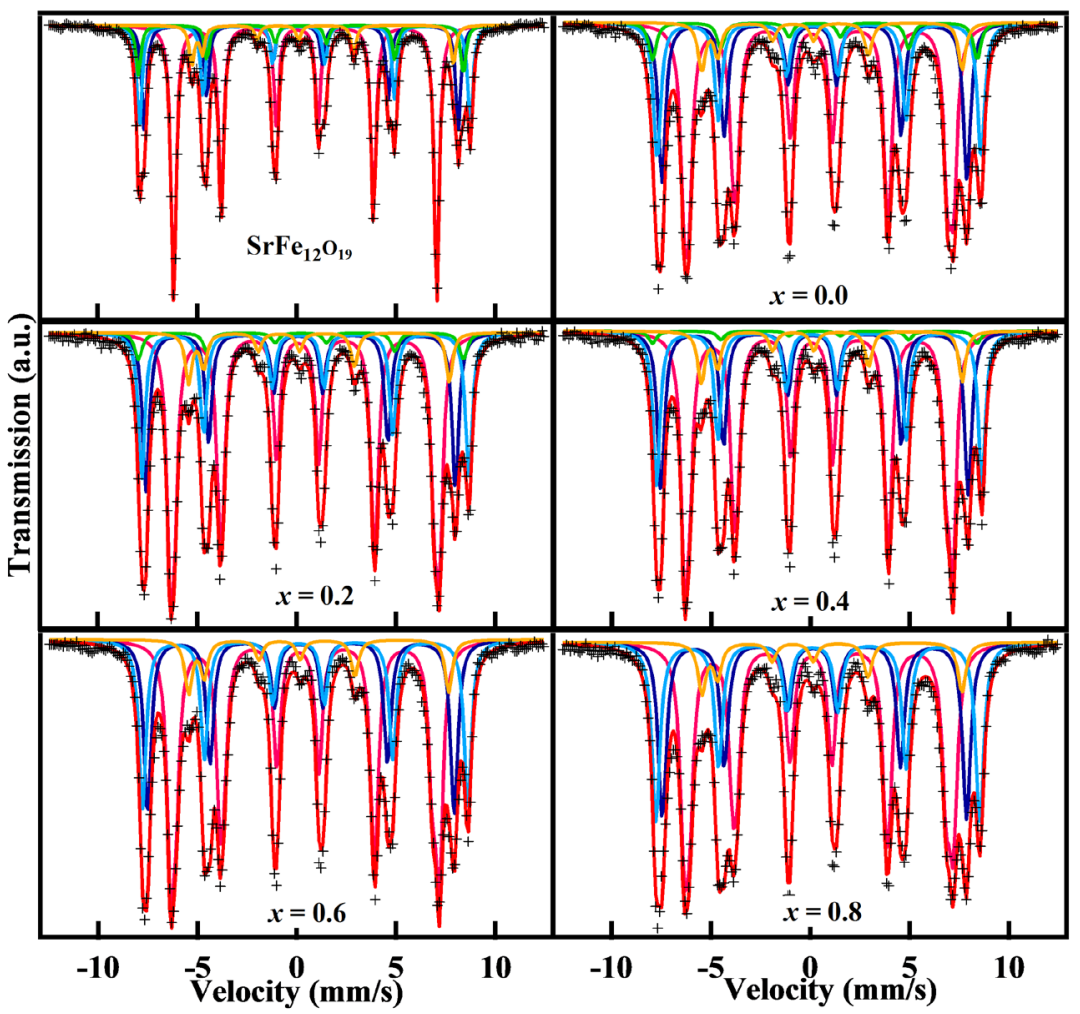

(a)

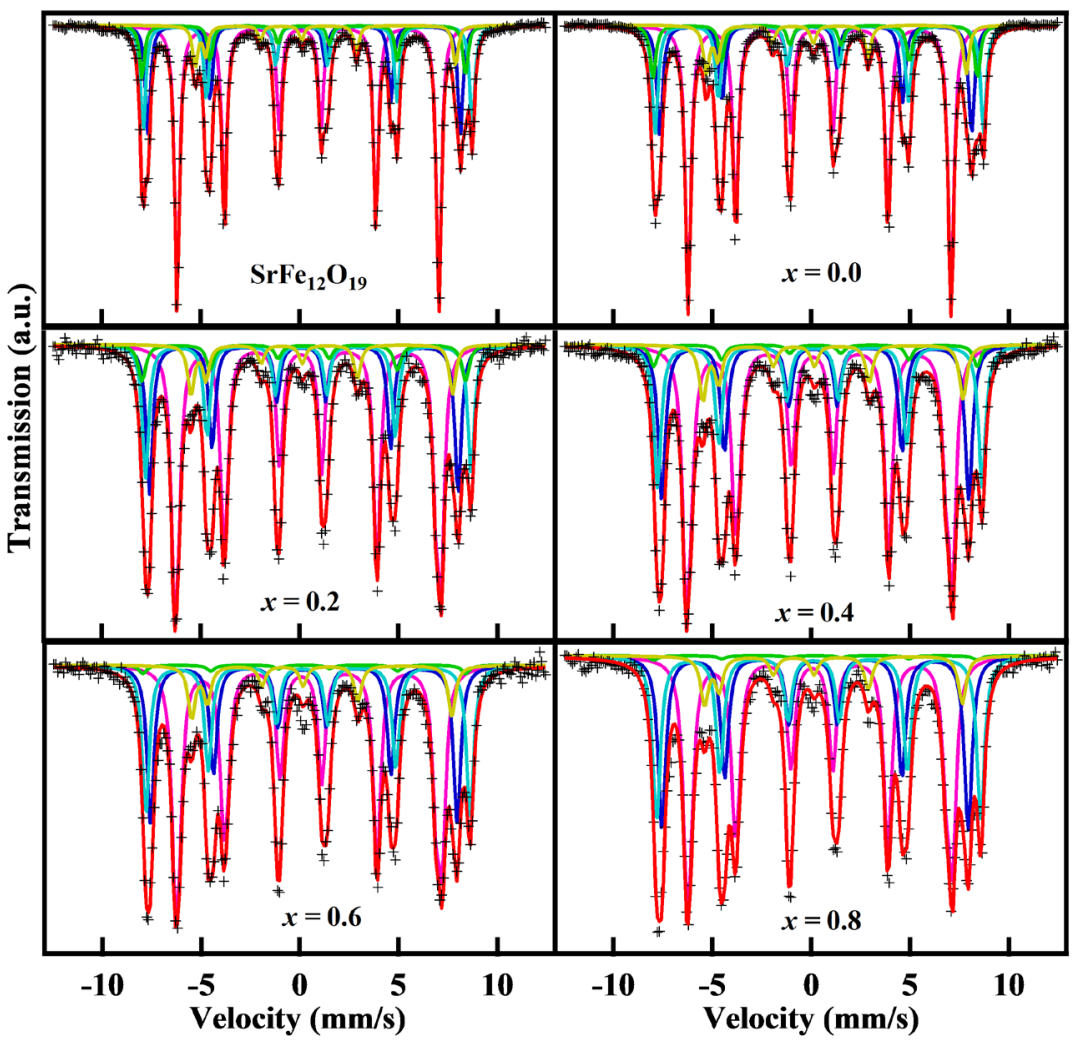

(b)

Figure 7. Room temperature fitted Mössbauer spectra of (a) $\mathrm{Sr}_{0.7} \mathrm{La}_{0.3} \mathrm{Fe}_{12-2 x} \mathrm{Co}_{\mathrm{x}} \mathrm{Al}_{\mathrm{x}} \mathrm{O}_{19}$ and (b) $\mathrm{Sr}_{0.7} \mathrm{Pr}_{0.3} \mathrm{Fe}_{12-2 \mathrm{x}} \mathrm{Co}_{\mathrm{x}} \mathrm{Al}_{\mathrm{x}} \mathrm{O}_{19}$ respectively. 
Table 4. (a) Hyperfine parameters of $\mathrm{Sr}_{0.7} \mathrm{La}_{0.3} \mathrm{Fe}_{12-2 \mathrm{x}} \mathrm{Co}_{\mathrm{x}} \mathrm{Al}_{\mathrm{x}} \mathrm{O}_{19}$ extracted from fitting room temperature Mossbauer spectra; (b) Hyperfine parameters of $\mathrm{Sr}_{0.7} \mathrm{Pr}_{0.3} \mathrm{Fe}_{12-2 \mathrm{x}} \mathrm{Co}_{\mathrm{x}} \mathrm{Al}_{\mathrm{x}} \mathrm{O}_{19}$ extracted from fitting room temperature Mossbauer spectra.

(a)

\begin{tabular}{|c|c|c|c|c|c|}
\hline $\mathrm{Sr}_{0.7} \mathrm{La}_{0.3} \mathrm{Fe}_{12-2 \mathrm{x}} \mathrm{Co}_{\mathrm{x}} \mathrm{Al}_{\mathrm{x}} \mathrm{O}_{19}$ & $\mathrm{x}$ & $\mathrm{HF}(\mathrm{kOe})$ & $\mathrm{QS}(\mathrm{mm} / \mathrm{s})$ & IS $(\mathrm{mm} / \mathrm{s})$ & Area (\%) \\
\hline \multirow{6}{*}{$12 k(\uparrow)$} & $\mathrm{SrFe}_{12} \mathrm{O}_{19}$ & 411.50 & 0.20 & 0.23 & 47.60 \\
\hline & 0.0 & 413.52 & 0.18 & 0.23 & 44.23 \\
\hline & 0.2 & 412.38 & 0.18 & 0.23 & 47.06 \\
\hline & 0.4 & 413.66 & 0.17 & 0.23 & 46.97 \\
\hline & 0.6 & 413.73 & 0.17 & 0.23 & 46.26 \\
\hline & 0.8 & 416.37 & 0.18 & 0.24 & 43.50 \\
\hline \multirow{6}{*}{$4 f 1(\downarrow)$} & $\mathrm{SrFe}_{12} \mathrm{O}_{19}$ & 491.00 & 0.09 & 0.15 & 18.20 \\
\hline & 0.0 & 477.73 & 0.05 & 0.15 & 23.20 \\
\hline & 0.2 & 483.92 & 0.06 & 0.15 & 21.81 \\
\hline & 0.4 & 480.87 & 0.06 & 0.15 & 22.72 \\
\hline & 0.6 & 480.11 & 0.05 & 0.15 & 23.81 \\
\hline & 0.8 & 475.82 & 0.05 & 0.16 & 24.63 \\
\hline \multirow{6}{*}{$4 f 2(\downarrow)$} & $\mathrm{SrFe}_{12} \mathrm{O}_{19}$ & 517.4 & 0.15 & 0.27 & 26.6 \\
\hline & 0.0 & 507.18 & 0.17 & 0.26 & 20.05 \\
\hline & 0.2 & 511.62 & 0.18 & 0.26 & 20.15 \\
\hline & 0.4 & 509.46 & 0.18 & 0.26 & 21.37 \\
\hline & 0.6 & 509.23 & 0.16 & 0.25 & 22.81 \\
\hline & 0.8 & 506.32 & 0.14 & 0.25 & 24.90 \\
\hline \multirow{6}{*}{$2 a(\uparrow)$} & $\mathrm{SrFe}_{12} \mathrm{O}_{19}$ & 508.10 & 0.00 & 0.22 & 8.70 \\
\hline & 0.0 & 508.10 & 0.00 & 0.22 & 5.60 \\
\hline & 0.2 & 508.10 & 0.00 & 0.22 & 4.14 \\
\hline & 0.4 & 508.10 & 0.00 & 0.22 & 1.84 \\
\hline & 0.6 & - & - & - & - \\
\hline & 0.8 & - & - & - & - \\
\hline \multirow{6}{*}{$2 b(\uparrow)$} & $\mathrm{SrFe}_{12} \mathrm{O}_{19}$ & 409.10 & 1.12 & 0.19 & 7.00 \\
\hline & 0.0 & 407.55 & 0.98 & 0.10 & 6.92 \\
\hline & 0.2 & 407.49 & 1.01 & 0.12 & 6.84 \\
\hline & 0.4 & 408.37 & 0.97 & 0.10 & 7.10 \\
\hline & 0.6 & 407.23 & 0.99 & 0.11 & 7.12 \\
\hline & 0.8 & 406.20 & 0.99 & 0.11 & 6.98 \\
\hline
\end{tabular}


(b)

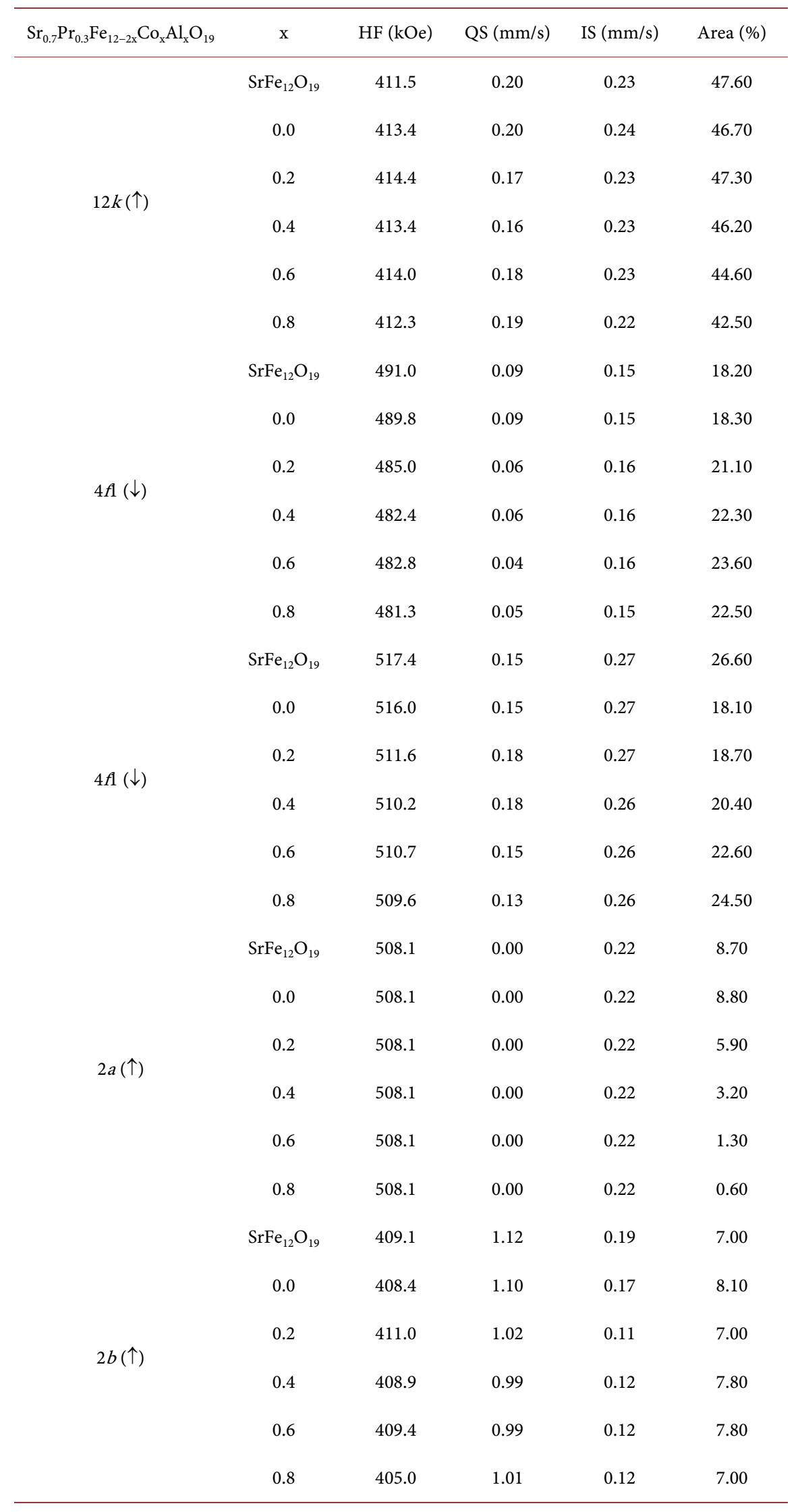


with $x$ in $\operatorname{Pr}^{3+}$-SrM, while $H F$ increases with $x$ in the $\mathrm{La}^{3+}-\mathrm{SrM}$ sample. The increase in $H F$ value of $\mathrm{La}^{3+}$-SrM is in agreement with the observed increase in the saturation magnetization, $M s$, with content $x$. Other lines $4 f 1,2 a$, and $4 f 2$ show a monotonous decrease in HF with $x$.

The isomer shift plot as a function of $x$ is shown in Figure 8. The isomer shift, $\delta$, for both series of samples for all sites visibly remains invariant except for the $2 b$ site. Also, the $2 b$ site's isomer shift value clearly reflects the influence of the
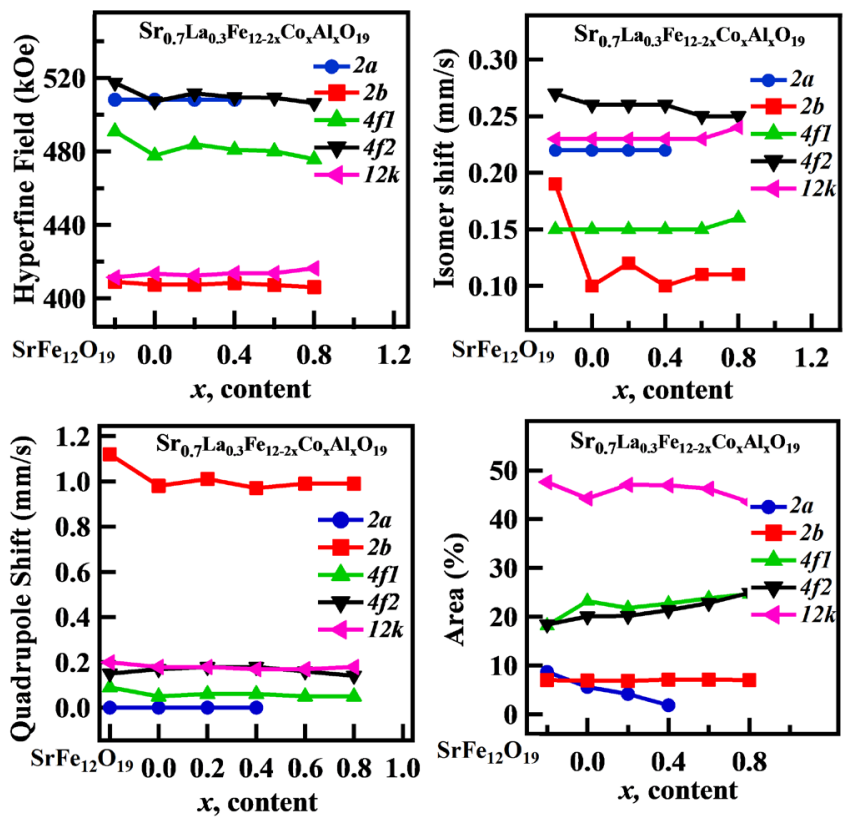

(a)
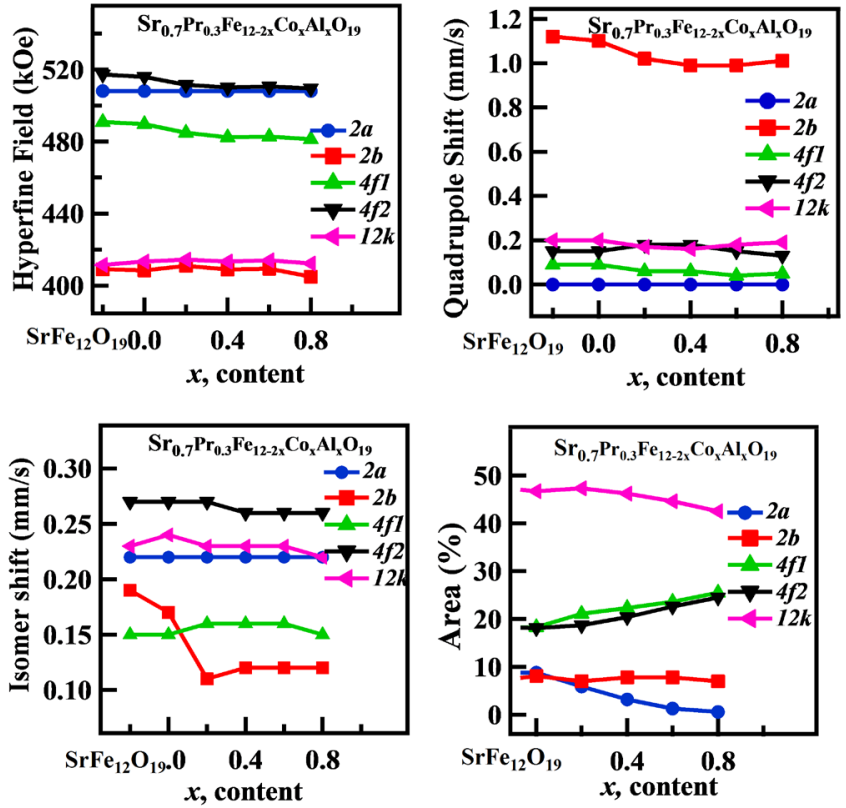

(b)

Figure 8. Room temperature hyperfine parameters of $\mathrm{Sr}_{0.7} \mathrm{La}_{0.3} \mathrm{Fe}_{12-2 \mathrm{x}} \mathrm{Co}_{\mathrm{x}} \mathrm{Al}_{\mathrm{x}} \mathrm{O}_{19}$ and $\mathrm{Sr}_{0.7} \mathrm{Pr}_{0.3} \mathrm{Fe}_{12-2 \mathrm{x}} \mathrm{Co}_{\mathrm{x}} \mathrm{Al}_{\mathrm{x}} \mathrm{O}_{19}$ obtained from Mossbauer spectral analysis. 
rare-earth ion in the compound. In the presence of rare-earth ion, the isomer shift value of $2 b$ drops significantly as compared to that of a pure $\operatorname{SrFe}_{12} \mathrm{O}_{19}$ compound. Isomer shift is a measure of $3 \mathrm{~d}$ electron density at the nucleus of the $\mathrm{Fe}$ atom. The closest sites of $\mathrm{Sr}^{2+}$ sites are $12 k, 4 f 2$, and $2 b$. The $2 b$ sites are located in the same plane as $\mathrm{Sr}^{2+}$ ions (at a distance of $0.340 \mathrm{~nm}$ ), while the $4 f 2$ and $12 k$ sites are located in the adjacent planes at nearly the same distance from $\mathrm{Sr}^{2+}$ viz. $\mathrm{Sr}^{2+}-12 k \sim 0.365 \mathrm{~nm}$ and $\left.\mathrm{Sr}^{2+}-4 f 2 \sim 0.366\right) \mathrm{nm}$ [48] [49]. Pr [Xe] $4 \mathrm{f}^{3} 6 \mathrm{~s}^{2}$ and $\mathrm{La}[\mathrm{Xe}] 5 \mathrm{~d}^{1} 6 \mathrm{~s}^{2}$ with more electrons as compared to $\mathrm{Sr}\left(\mathrm{Kr}\left[5 \mathrm{~s}^{2+}\right]\right)$ has a negative effect on the isomer shift, that is increased substitution of $\mathrm{Pr}^{3+}$ or $\mathrm{La}^{3+}$ increases the net $s$-electron charge density at the $2 b$ site, which in turn decreases the isomer shift value at the $2 b$ site.

The quadrupole shift, QS, values of $2 b$ site show a similar $\sim 10 \%$ drop in both $\mathrm{Pr}^{3+}$ and $\mathrm{La}^{3+}$ substituted samples. The quadrupole values for all sites remain invariant with $x$ for both series of samples. It is known that QS is a measure of the asymmetry of a crystallographic site. Since the $2 b$ sites are located in the same plane as $\mathrm{Sr}^{2+}$, the substitution of the smaller $\mathrm{Pr}^{3+}$ and $\mathrm{La}^{3+}$ for $\mathrm{Sr}^{2+}$ ions induces a deformation, which affects the electronic site symmetry of the nearby $2 b$ site. Due to the substitution of smaller $\mathrm{La}^{3+}$ and $\mathrm{Pr}^{3+}$ ion for $\mathrm{Sr}^{2+}$ ion, the lattice constant $c$ contracts. Consequently, large Fe-O distances parallel to the $c$-axis decreases. As a result, the oxygen bipyramid of the $2 b$-site becomes more symmetric, which is in agreement with the observed reduction in the quadrupole shift value with content $x$. A similar decrease in $2 b$ quadrupole splitting originating from the presence of $\mathrm{La}^{3+}$ substitution has been reported in $\mathrm{Sr}_{1-\mathrm{x}} \mathrm{La}_{\mathrm{x}} \mathrm{Fe}_{12-\mathrm{y}} \mathrm{Co}_{\mathrm{y}} \mathrm{O}_{19}$ [39].

A close examination of the fitted spectra shows a decreasing trend of $2 a$ absorption intensities with increasing $x$. Without $\mathrm{Co}^{2+}-\mathrm{Al}^{3+}$ co-doping, the intensity of $2 a$ site lines in both $\mathrm{Sr}_{0.7} \mathrm{La}_{0.3} \mathrm{Fe}_{12} \mathrm{O}_{19}$ and $\mathrm{Sr}_{0.7} \mathrm{Pr}_{0.3} \mathrm{Fe}_{12} \mathrm{O}_{19}$ are nearly the same as that of undoped $\mathrm{SrFe}_{12} \mathrm{O}_{19}$. However, with the substitution of $\mathrm{Co}^{2+}-\mathrm{Al}^{3}$, the $2 \mathrm{a}$ absorption area decreased linearly and finally disappeared at $x=0.6$ and 1.0 for $\mathrm{La}^{3+}-\mathrm{SrM}$ and $\mathrm{Pr}^{3+}-\mathrm{SrM}$ sample, respectively. This suggests preferential occupation of $\mathrm{Co}^{2+}-\mathrm{Al}^{3}$ for the $2 a$ site. It has already been reported that $\mathrm{Al}^{3+}$ ion prefers $12 k$ and $2 a$ site [50] while $\mathrm{Co}^{2+}$ was reported to enter $4 f 2$ site in $\mathrm{Sr}_{1-\mathrm{x}} \mathrm{La}_{\mathrm{x}} \mathrm{Fe}_{12-\mathrm{x}} \mathrm{Co}_{\mathrm{x}} \mathrm{O}_{19}$ [51]. There is only one $2 a$ site in every one formula unit of M-type hexaferrite. Therefore, the fact that the $2 a$ absorption line of $\mathrm{Sr}_{0.7} \mathrm{La}_{0.3} \mathrm{Fe}_{12-2 \mathrm{x}} \mathrm{Co}_{\mathrm{x}} \mathrm{Al}_{\mathrm{x}} \mathrm{O}_{19}$ disappeared completely at $x=0.6$ means that all the $\mathrm{Co}^{2+}-\mathrm{Al}^{3}$ dopants almost exclusively go into $2 a$ site. In the case when $x>0.5$, the excessive $\mathrm{Co}^{2+}-\mathrm{Al}^{3}$ dopant should occupy the crystallographic sites other than the $2 a$ site. On the other hand, in the case of $\mathrm{Sr}_{0.7} \mathrm{Pr}_{0.3} \mathrm{Fe}_{12-2 \mathrm{x}} \mathrm{Co}_{\mathrm{x}} \mathrm{Al}_{\mathrm{x}} \mathrm{O}_{19}, 2 a$ absorption intensity has decreased linearly and has completely diminished at $x=1.0$, which indicates that all the $2 a$ sites become full when $x=1.0$. This suggests that only half of the $\mathrm{Co}^{2+}-\mathrm{Al}^{3+}$ dopant occupies the 2 a site compared to the case of the $\mathrm{La}^{3+}-\mathrm{SrM}$ sample. Then, the other half of the $2 a$ site should be occupied by $\mathrm{Fe}^{3+}$ ions through the range of $x$ examined. In the case of $\operatorname{Pr}^{3+}$ series samples, a slight decline in the absorption area 
for the most intense $12 k$ site is observed, while in the $\mathrm{La}^{3+}$ containing samples, $12 k$ areal almost remains constant. Thus it seems that the excessive $\mathrm{Co}^{2+}-\mathrm{Al}^{3+}$ dopant occupies the $2 a$ site and $12 k$ site in $\mathrm{Sr}_{0.7} \mathrm{Pr}_{0.3} \mathrm{Fe}_{12-2 \mathrm{x}} \mathrm{Co}_{\mathrm{x}} \mathrm{Al}_{\mathrm{x}} \mathrm{O}_{19}$. The above observation clearly indicates that the tendency of $12 \mathrm{k}$ site occupation by the $\mathrm{Co}^{2+}-\mathrm{Al}^{3+}$ dopant is affected by the species of rare-earth ions at the $\mathrm{Sr}^{2+}$ site. Where $\mathrm{Co}^{2+}-\mathrm{Al}^{3+}$ impurity mostly prefers $2 a$ site and its preference for $12 k$ site is enhanced in the presence of $\mathrm{Pr}^{3+}$ rather than $\mathrm{La}^{3+}$, once the $2 a$ site is completely filled. This observation is interesting considering the fact that there are no $2 a$ sites in the vicinity of $\mathrm{Sr}^{2+}$, and hence the substitution at $\mathrm{Sr}^{2+}$ with rare-earth ions is not expected to influence the site occupancy at the $2 a$ site. Furthermore, the physical reason for the preferential site occupancy of $\mathrm{Co}^{2+}-\mathrm{Al}^{3+}$ in the presence of $\mathrm{La}^{3+}$ or $\mathrm{Pr}^{3+}$ is not clear at this stage. Mossbauer spectroscopy cannot discriminate against the site occupancies of both $\mathrm{Co}^{2+}$ and $\mathrm{Al}^{3+}$ ions separately. But one scenario is that $\mathrm{Co}^{2+}$ ions might not prefer the $2 a$ site in the presence of $\mathrm{Pr}^{3+}$ ion, which needs further investigation.

\section{Conclusion}

The structural, magnetic, and Mossbauer spectrum study of the influence of rare-earth $\mathrm{La}^{3+}$ and $\mathrm{Pr}^{3+}$ on $\mathrm{Sr}_{0.7} \mathrm{RE}_{0.3} \mathrm{Fe}_{12-2 \mathrm{x}} \mathrm{Co}_{\mathrm{x}} \mathrm{Al}_{\mathrm{x}} \mathrm{O}_{19}$, (RE: $\mathrm{La}$ and $\mathrm{Pr}$ ) hexaferrite compounds were investigated. Overall, dopant ion brings a unit cell contraction, which affects the Curie temperature and saturation magnetization of both series of samples. $\mathrm{La}^{3+}-\mathrm{SrM}$ samples show marked improvement in the magnetization value, while $\mathrm{Pr}^{3+}-\mathrm{SrM}$ samples show deterioration in $M s$ value with the $\mathrm{Co}^{2+}-\mathrm{Al}^{3+}$ substitution. This is suggestive of the fact that magnetic $\mathrm{Pr}^{3+}$, unlike non-magnetic $\mathrm{La}^{3+}$ (no $4 f$ electrons), substitution for $\mathrm{Sr}^{2+}$ could be detrimental to the overall magnetization behavior of the $\mathrm{SrFe}_{12} \mathrm{O}_{19}$ compound. The $\mathrm{Co}^{2+}-\mathrm{Al}^{3+}$ substitution brings in grain refinement, more for the $\mathrm{La}^{3+}-\mathrm{SrM}$ than $\mathrm{Pr}^{3+}-\mathrm{SrM}$, which has a considerable impact on the coercivity values of the compound. The Mossbauer spectral analysis revealed $2 a$ as a preferred substitution for $\mathrm{Co}^{2+}-\mathrm{Al}^{3+}$ ions for both series of samples. Due to lattice contraction, the $2 b$ site displayed a considerable reduction in its quadrupole shift value. The improved hyperfine field for the $12 k$ site in the $\mathrm{La}^{3+}-\mathrm{SrM}$ series is attributed to the increase in its magnetization value with the substitution of $\mathrm{Co}^{2+}-\mathrm{Al}^{3+}$ ions for $\mathrm{Fe}^{3+}$. For the study, it is concluded that the substitution of rare-earth ions with $4 f$ charge distribution for $\mathrm{Sr}^{2+}$ could be detrimental to the overall magnetic performance of the M-type hexaferrite materials.

\section{Conflicts of Interest}

The authors declare no conflicts of interest regarding the publication of this paper.

\section{References}

[1] Chen, N., Yang, K. and Mingyuan, G. (2010) Microwave Absorption Properties of 
La-Substituted M-Type Strontium Ferrites. Journal of Alloys and Compounds, 490, 609-612. https://doi.org/10.1016/j.jallcom.2009.10.116

[2] Riches, E.E. (1972) Ferrites: A Review of Materials and Applications. 3rd Edition, Mills \& Boon, Richmond.

[3] Chin, T.-S. (2000) Permanent Magnet Films for Applications in Microelectromechanical Systems. Journal of Magnetism and Magnetic Materials, 209, 75-79. https://doi.org/10.1016/S0304-8853(99)00649-6

[4] Hernandez, P., De Francisco, C., Munoz, J.M., Iniguez, J., Torres, L. and Zazo, M. (1996) Influence of Sintering Atmosphere on the Magnetic After-Effect in Strontium Ferrites. Journal of Magnetism and Magnetic Materials, 157-158, 123-124. https://doi.org/10.1016/0304-8853(95)01070-X

[5] Jin, Z.Q., Tang, W., Zhang, J.R., Lin, H. and Du, Y.W. (1998) Magnetic Properties of Isotropic $\mathrm{SrFe}_{12} \mathrm{O}_{19}$ Fine Particles Prepared by Mechanical Alloying. Journal of Magnetism and Magnetic Materials, 182, 231-237. https://doi.org/10.1016/S0304-8853(97)00679-3

[6] Qiao, L., You, L., Zheng, J., Jiang, L. and Sheng, J. (2007) The Magnetic Properties of Strontium Hexaferrites with La-Cu Substitution Prepared by SHS Method. Journal of Magnetism and Magnetic Materials, 318, 74-78.

https://doi.org/10.1016/j.jmmm.2007.04.028

[7] Beseničar, S. and Miha, D. (1991) High Coercivity Sr Hexaferrites. Journal of Magnetism and Magnetic Material, 101, 307-309.

https://doi.org/10.1016/0304-8853(91)90763-Z

[8] Rezlescu, L., Rezlescu, E., Popa, P.D. and Rezlescu, N. (1999) Fine Barium Hexaferrite Powder Prepared by the Crystallization of Glass. Journal of Magnetism and Magnetic Materials, 193, 288-290. https://doi.org/10.1016/S0304-8853(98)00442-9

[9] Zhong, W., Ding, W.P., Zhang, N., Hong, J.M., Yan, Q.J. and Du, Y.W. (1997) Key Step in Synthesis of Ultrafine $\mathrm{BaFe}_{12} \mathrm{O}_{19}$ by Sol-Gel Technique. Journal of Magnetism and Magnetic Materials, 168, 196-202. https://doi.org/10.1016/S0304-8853(96)00664-6

[10] Kojima, H. (1982) Chapter 5. Fundamental Properties of Hexagonal Ferrites with Magnetoplumbite Structure. In: Handbook of Ferromagnetic Materials, Elsevier, Amsterdam, Vol. 3, 305-391. https://doi.org/10.1016/S1574-9304(05)80091-4

[11] Luo, H., Rai, B.K., Mishra, S.R., Nguyen, N.N. and Liu, J.P. (2012) Physical and Magnetic Properties of Highly Aluminum Doped Strontium Ferrite Nanoparticles Prepared by Auto-Combustion Route. Journal of Magnetism and Magnetic Materials, 324, 2602-2608. https://doi.org/10.1016/j.jmmm.2012.02.106

[12] Shirtcliffe, N.J., Thompson, S., O’keefe, E.S. Appleton, S. and Perry, C.C. (2007) Highly Aluminium Doped Barium and Strontium Ferrite Nanoparticles Prepared by Citrate Auto-Combustion Synthesis. Materials Research Bulletin, 42, 281-287. https://doi.org/10.1016/j.materresbull.2006.06.001

[13] Fang, Q.Q., Liu, Y.M., Yin, P. and Li, X.G. (2001) Magnetic Properties and Formation of Sr Ferrite Nanoparticle and Zn, Ti/Ir Substituted Phases. Journal of Magnetism and Magnetic Materials, 234, 366-370. https://doi.org/10.1016/S0304-8853(01)00428-0

[14] Iqbal, M.J., Ashiq, M.N., Gomes, P.H. and Munoz, J.M. (2008) Synthesis, Physical, Magnetic and Electrical Properties of Al-Ga Substituted Co-Precipitated Nanocrystalline Strontium Hexaferrite. Journal of Magnetism and Magnetic Materials, 320, 881-886. https://doi.org/10.1016/j.jmmm.2007.09.005 
[15] Albanese, G., Carbucicchio, M. and Deriu, A. (1974) Temperature Dependence of the Sublattice Magnetizations in Al- and Ga-Substituted M-Type Hexagonal Ferrites. Physica Status Solidi, 23, 351-358. https://doi.org/10.1002/pssa.2210230202

[16] Ashiqa, M.N., Iqbalb, M.J. and Gulc, I.H. (2009) Structural, Magnetic and Dielectric Properties of Zr-Cd Substituted Strontium Hexaferrite $\left(\mathrm{SrFe}_{12} \mathrm{O}_{19}\right)$ Nanoparticles. Journal of Alloys and Compounds, 487, 341-345. https://doi.org/10.1016/j.jallcom.2009.07.140

[17] Le Breton, J.M., Teillet, J., Wiesinger, G., Morel, A., Kools, F. and Tenaud, P. (2002) Mossbauer Investigation of $\mathrm{Sr}-\mathrm{Fe}-\mathrm{O}$ Hexaferrites with La-Co Addition. IEEE Transactions on Magnetics, 38, 2952-2954. https://doi.org/10.1109/TMAG.2002.803177

[18] Nourbakhsh, A.A., Noorbakhsh, M., Nourbakhsh, M., Shaygan, M. and Mackenzie, K.J.D. (2011) The Effect of Nano Sized $\mathrm{SrFe}_{12} \mathrm{O}_{19}$ Additions on the Magnetic Properties of Chromium-Doped Strontium-Hexaferrite Ceramics. Journal of Materials Science: Materials in Electronics, 22, 1297-1302. https://doi.org/10.1007/s10854-011-0303-3

[19] Liu, X.S., Zhong, W., Yang, S., Yu, Z., Gu, B.X. and Du, Y. (2002) Structure and Magnetic Properties of $\mathrm{La}^{3+}$-Substituted Strontium Hexaferrite Particles Prepared by Sol-Gel Method. Physica Status Solidi, 193, 314-319. https://doi.org/10.1002/1521-396X(200209)193:2<314::AID-PSSA314>3.0.CO;2-W

[20] Dahal, J.N., Neupane, D. and Mishra, S.R. (2019) Exchange-Coupling Behavior in $\mathrm{SrFe}_{12} \mathrm{O}_{19} / \mathrm{La}_{0.7} \mathrm{Sr}_{0.3} \mathrm{Mno}_{0.3}$ Nanocomposites. Ceramics, 2, 100-111. https://doi.org/10.3390/ceramics2010010

[21] Mocuta, H., Lechevallier, L., Le Breton, J.M., Wang, J.F. and Harris, I.R. (2004) Structural and Magnetic Properties of Hydrothermally Synthesised $\mathrm{Sr}_{1-\mathrm{x}} \mathrm{Nd}_{\mathrm{x}} \mathrm{Fe}_{12} \mathrm{O}_{19}$ Hexagonal Ferrites. Journal of Alloys and Compounds, 364, 48-52. https://doi.org/10.1016/S0925-8388(03)00545-0

[22] Lechevallier, L., Le Breton, J.M., Wang, J.F. and Harris, I.R. (2004) Structural and Magnetic Properties of Hydrothermally Synthesised $\mathrm{Sr}_{1-\mathrm{x}} \mathrm{Nd}_{\mathrm{x}} \mathrm{Fe}_{12} \mathrm{O}_{19}$ Hexagonal Ferrites. Journal of Magnetism and Magnetic Materials, 269, 192-196. https://doi.org/10.1016/S0304-8853(03)00591-2

[23] Wang, J.F., Ponton, C.B. and Harris, I.R. (2001) A Study of the Magnetic Properties of Hydrothermally Synthesised Sr Hexaferrite with Sm Substitution. Journal of Magnetism and Magnetic Materials, 234, 233-240. https://doi.org/10.1016/S0304-8853(01)00366-3

[24] Lechevallier, L., Le Breton, J.M., Morel, A. and Tenaud, P. (2008) On the Solubility of Rare Earths in M-Type $\mathrm{SrFe}_{12} \mathrm{O}_{19}$ Hexaferrite Compounds. Journal of Physics: Condensed Matter, 20, Article ID: 175203. https://doi.org/10.1088/0953-8984/20/17/175203

[25] Polyko, D.D., Bashkirov, L.A., Trukhanov, S.V., Lobanovskii, L.S. and Sirota, I.M. (2011) Crystal Structure and Magnetic Properties of High-Coercivity $\operatorname{Sr}_{1-x} \operatorname{Pr}_{\mathrm{x}}$ $\mathrm{Fe}_{12-\mathrm{x}} \mathrm{Zn}_{\mathrm{x}} \mathrm{O}_{19}$ Solid Solutions. Inorganic Materials, 47, 77-79. https://doi.org/10.1134/S0020168511010110

[26] Yang, Y.J. and Liu, X.S. (2014) Microstructure and Magnetic Properties of La-Cu Doped M-Type Strontium Ferrites Prepared by Ceramic Process. Materials Technology, 29, 232-236.

[27] Corral Huacuz, J.C. and Mendoza-Suárez, G. (2002) Preparation and Magnetic Properties of Ir-Co and La-Zn Substituted Barium Ferrite Powders Obtained by Sol-Gel. Journal of Magnetism and Magnetic Materials, 430, 430-433. 
https://doi.org/10.1016/S0304-8853(01)01141-6

[28] Torkian, S., Ghasemi, A., Shojarazavi, R. and Tavoosi, M. (2016) Structural and Magnetic Properties of High Coercive Al-Substituted Strontium Hexaferrite Nanoparticles. Journal of Superconducativity and Novel Magnetism, 29, 1627-1640. https://doi.org/10.1007/s10948-016-3450-1

[29] Trusov, L.A., Gorbachev, E.A., Lebedev, V.A., Sleptsova, A.E., Roslyakov, I.V., Kozlyakova, E.S., Vasiliev, A.V., Dinnebier, R.E. Jansen, M. and Kazin, P.E. (2018) Ca-Al Double-Substituted Strontium Hexaferrites with Giant Coercivity, Chemical Communications, 54, 479-482. https://doi.org/10.1039/C7CC08675J

[30] Narang, S.B., Singh, A. and Singh, K. (2014) High Frequency Dielectric Behavior of Rare Earth Substituted Sr-M Hexaferrite. Journal of Ceramic Processing Research, 8, 347.

[31] Shannon, R.D. (1976) Revised Effective Ionic Radii and Systematic Studies of Interatomic Distances in Halides and Chalcogenides. Acta Crystallographica, A32, 751-767. https://doi.org/10.1107/S0567739476001551

[32] Wagner, T.R. (1998) Preparation and Crystal Structure Analysis of Magnetoplumbite-Type $\mathrm{Baga}_{12} \mathrm{O}_{19}$. Journal of Solid State Chemistry, 136, 120-124.

https://doi.org/10.1006/jssc.1997.7681

[33] Cullity, B.D. (1956) Elements of X-Ray Diffraction. 2nd Edition, Addison-Wesley Publishing, Boston.

[34] Dahal, J.N., Wang, L., Mishra, S.R., Nguyen, V.V., and Liu, J.P. (2014) Synthesis and Magnetic Properties of $\mathrm{SrFe}_{12-\mathrm{x}-\mathrm{y}} \mathrm{Al}_{\mathrm{x}} \mathrm{Co}_{\mathrm{y}} \mathrm{O}_{19}$ Nanocomposites Prepared via Autocombustion Technique. Journal of Alloys and Compounds, 595, 213-220. https://doi.org/10.1016/j.jallcom.2013.12.186

[35] Zi, Z.F., Sun, Y.P., Zhu, X.B., Yang, Z.R. and Song, W.H. (2008) Structural and Magnetic Properties of $\mathrm{SrFe}_{12} \mathrm{O}_{19}$ Hexaferrite Synthesized by a Modified Chemical Co-Precipitation Method. Journal of Magnetism and Magnetic Materials, 320, 2746-2751. https://doi.org/10.1016/j.jmmm.2008.06.009

[36] Wiesinger, G., Muller, M., Grossinger, R., Pieper, M., Morel, A., Kools, F., Tenad, P., Le Breton, J.M. and Kreisel, J. (2002) Substituted Ferrites Studied by Nuclear Methods. Physica Status Solidi, 189, 499-508. https://doi.org/10.1002/1521-396X(200202)189:2<499::AID-PSSA499>3.0.CO;2-H

[37] Lechevallier, L., Le Breton, J.M., Teillet, J. Morel, A., Kools, F. and Tenaud, P. (2003) Mössbauer Investigation of $\mathrm{Sr}_{1-\mathrm{x}} \mathrm{La}_{\mathrm{x}} \mathrm{Fe}_{12-\mathrm{y}} \mathrm{Co}_{\mathrm{y}} \mathrm{O}_{19}$ Ferrites. Physica B: Condensed Matter, 327, 135-139. https://doi.org/10.1016/S0921-4526(02)01712-X

[38] Le Breton, J.-M., Teillet, J., Wiesinger, G., Morel, A., Kools, F. and Tenaud, P. (2002) Mossbauer Investigation of Sr-Fe-O Hexaferrites La-Co Addition. IEEE Transactions on Magnetics, 38, 2952-2954. https://doi.org/10.1109/TMAG.2002.803177

[39] Kools, F. ((1985) Factors Governing the Coercivity of Sintered Anisotropic M Type Ferrite. Le Journal de Physique Colloques, 46, 346-349.

[40] Zhou, X.Z., Morrish, A.H., Li, Z.W. and Hong, Y.K. (1991) Site Preference for $\mathrm{Co}^{2+}$ and $\mathrm{Ti}^{4+}$ in Co-Ti Substituted Barium Ferrites. IEEE Transactions on Magnetics, 27, 4654-4656. https://doi.org/10.1109/20.278906

[41] Han, D.H., Yang, Z., Zeng, H.X., Zhou, X.Z. and Morrish, A.H. (1994) Cation Site Preference and Magnetic Properties of Co-Sn-Substituted Ba Ferrites Particles. Journal of Magnetism and Magnetic Materials, 137, 191-196. https://doi.org/10.1016/0304-8853(94)90205-4 
[42] Choi, D.H., An, S.Y., Lee, S.W., Shim, I.-B. and Kim, C.S. (2004) Site Occupancy and Anisotropy Distribution of Al Substituted Ba-Ferrite with High Coercivity. Physica State Solid, 241, 1736-1739. https://doi.org/10.1002/pssb.200304633

[43] Albanese, G. (1995) Mossbauer Investigation of Aluminium Substituted Barium Hexaferrites in the Paramagnetic State. Journal of Magnetism and Magnetic Materials, 147, 421-426. https://doi.org/10.1016/0304-8853(95)00063-1

[44] Lechevallier, L., Le Breton, J.M., Morel, A. and Tenaud, P. (2007) Influence of the Presence of Co on the Rare Earth Solubility in M-Type Hexaferrite Powders. Journal of Magnetism and Magnetic Materials, 316, e109-e111. https://doi.org/10.1016/j.jmmm.2007.02.042

[45] Ghimire, M., Yoon, S., Wang, S.L., Neupane, D., Alam, J. and Mishra, S.R. (2018) Influence of La Content on Magnetic Properties of $\mathrm{Cu}$ Doped M-Type Strontium Hexaferrite: Structural, Magnetic, and Mossbauer Spectroscopy Study. Journal of Magnetism and Magnetic Materials, 454, 110-120. https://doi.org/10.1016/j.jmmm.2018.01.062

[46] Kunwar, D.L., Neupane, D., Dahal, J.N. and Mishra, S.R. (2019) Structural, Magnetic, and Electrical Properties of Re Doped $\mathrm{Sr}_{0.82} \mathrm{Re}_{0.18} \mathrm{Fe}_{12-\mathrm{x}} \mathrm{Al}_{\mathrm{x}} \mathrm{O}_{19}(\mathrm{Re}=\mathrm{Gd}, \mathrm{Pr}$, Sm) Compound. Advances in Materials Physics and Chemistry, 9, 175. https://doi.org/10.4236/ampc.2019.99014

[47] Evans, B.J., Grandjean, F., Lilot, A.P., Vogel, R.H. and Gerard, A. (1987) ${ }^{57} \mathrm{Fe}$ Hyperfine Interaction Parameters and Selected Magnetic Properties of High Purity $\mathrm{MFe}_{12} \mathrm{O}_{19}(\mathrm{M}=\mathrm{Sr}, \mathrm{Ba})$. Journal of Magnetism and Magnetic Materials, 67, 123-129. https://doi.org/10.1016/0304-8853(87)90728-1

[48] Wartewig, P., Krause, M.K., Esquinazi, P., Rösler, S. and Sonntag, R. (1999) Magnetic Properties of $\mathrm{Zn}$ - and Ti-Substituted Barium Hexaferrite. Journal of Magnetism and Magnetic Materials, 192, 83-99. https://doi.org/10.1016/S0304-8853(98)00382-5

[49] Obradors, X., Solans, X.A., Collomb, D., Samaras, J., Rodriguez, M., Pernet, M. and Font-Altaba, M. (1988) Crystal Structure of Strontium Hexaferrite $\mathrm{SrFe}_{12} \mathrm{O}_{19}$. Journal of Solid State Chemistry, 72, 218-224. https://doi.org/10.1016/0022-4596(88)90025-4

[50] Dixit, V., Nandadasa, C.N., Kim, S.G., Kim, S., Park, J., Hong, Y.K. and Moitra, A. (2015) Site Occupancy and Magnetic Properties of Al-Substituted M-Type Strontium Hexaferrite. Journal of Applied Physics, 117, Article ID: 243904. https://doi.org/10.1063/1.4922867

[51] Lechevallier, L. and Le Breton, J.M. (2005) Substitution Effects in M-Type Hexaferrite Powders Investigated by Mössbauer Spectrometry. Journal of Magnetism and Magnetic Materials, 290, 1237-1239.

https://doi.org/10.1016/j.jmmm.2004.11.411 